\title{
Developmental Emergence of Phenotypes in the Auditory Brainstem Nuclei of Fmr1 Knockout Mice
}

\author{
Sarah E. Rotschafer and Karina S. Cramer \\ DOI:http://dx.doi.org/10.1523/ENEURO.0264-17.2017 \\ Department of Neurobiology and Behavior, University of California, Irvine, CA 92697
}

\begin{abstract}
Fragile X syndrome (FXS), the most common monogenic cause of autism, is often associated with hypersensitivity to sound. Several studies have shown abnormalities in the auditory brainstem in FXS; however, the emergence of these auditory phenotypes during development has not been described. Here, we investigated the development of phenotypes in FXS model [Fmr1 knockout (KO)] mice in the ventral cochlear nucleus (VCN), medial nucleus of the trapezoid body (MNTB), and lateral superior olive (LSO). We studied features of the brainstem known to be altered in FXS or Fmr1 KO mice, including cell size and expression of markers for excitatory (VGLUT) and inhibitory (VGAT) synapses. We found that cell size was reduced in the nuclei with different time courses. VCN cell size is normal until after hearing onset, while MNTB and LSO show decreases earlier. VGAT expression was elevated relative to VGLUT in the Fmr1 KO mouse MNTB by P6, before hearing onset. Because glial cells influence development and are altered in FXS, we investigated their emergence in the developing Fmr1 KO brainstem. The number of microglia developed normally in all three nuclei in Fmr1 KO mice, but we found elevated numbers of astrocytes in Fmr1 KO in VCN and LSO at P14. The results indicate that some phenotypes are evident before spontaneous or auditory activity, while others emerge later, and suggest that Fmr1 acts at multiple sites and time points in auditory system development.
\end{abstract}

Key words: auditory; brainstem; fragile $\mathrm{x}$; lateral superior olive; medial nucleus of the trapezoid body; ventral cochlear nucleus:

\section{Significance Statement}

Individuals with fragile $X$ syndrome (FXS) are hypersensitive to sound and show enhanced cortical responses to sound stimuli. Recent work suggests that functional and physiologic abnormalities in the auditory brainstem may contribute to the dysfunction found in the auditory system. We investigated the emergence of the FXS auditory brainstem phenotype in the development of auditory brainstem nuclei in FXS model mice ( $F m r 1 \mathrm{KO})$. We found that some of the reductions in cell size and imbalances in inhibitory/ excitatory input present in adult Fmr1 KO mice emerged early in postnatal development. This study suggests that even before hearing onset, loss of the Fmr1 gene drives disruptions in the auditory system.

\section{Introduction}

Fragile $X$ syndrome (FXS) results from transcriptional silencing of the FMR1 gene and reduced expression of fragile $\mathrm{X}$ mental retardation protein (FMRP; Bailey et al.,
1998; O’Donnell and Warren, 2002). Individuals with FXS often display communication disorders (Fidler et al., 2007; Finestack et al., 2009), repetitive behaviors (Feinstein and Reiss, 1998; Belser and Sudhalter, 2001; Baranek et al.,
Received July 27, 2017; accepted December 5, 2017; First published December 26, 2017.

Authors report no conflict of interest.

Author contributions: SER: collected and analyzed data, prepared the manuscript.

KSC: assisted with data analysis and interpretation, prepared the manuscript.
This project was supported by NIH National Institute on Deafness and Other Communication Disorders grant R01DC010796. In addition, the work was partially supported by grant UL1 TR001414 from the NIH National Center for Advancing Translational Sciences through the Biostatistics, Epidemiology and Research Design Unit. 
2005), and unusual social interactions (Hagerman et al., 1986); accordingly, FXS is the leading single-gene cause of inherited autism. FXS is also associated with hypersensitivity to sensory stimuli (Miller et al., 1999), especially auditory stimuli (Frankland et al., 2004; Roberts et al., 2005; Gothelf et al., 2008; Hessl et al., 2009; Yuhas et al., 2011). Dysfunction in FXS is evidenced by childhood temporal lobe seizures (Musumeci et al., 1991, 1999; Incorpora et al., 2002), exaggerated auditory cortical responses to sound (St Clair et al., 1987; Rojas et al., 2001; Castrén et al., 2003; Knoth and Lippé, 2012; Van der Molen et al., 2012a, b; Schneider et al., 2013; Knoth et al., 2014), and failure to habituate to sounds (Van der Molen et al., 2012a, b).

In addition to these cortical phenotypes, recent studies suggest that some aspects of auditory dysfunction in FXS arise in the auditory brainstem, particularly in nuclei that comprise the sound localization circuits. Auditory input from the periphery first contacts the cochlear nucleus, and axons from the ventral cochlear nucleus (VCN) send excitatory input to the ipsilateral lateral superior olive (LSO) and the contralateral medial nucleus of the trapezoid body (MNTB). In addition to the large calyx of Held excitatory input from VCN, MNTB also receives glycinergic and GABAergic inhibitory input from the ventral nucleus of the trapezoid body (VNTB; Albrecht et al., 2014). MNTB provides glycinergic inhibitory input to ipsilateral LSO, and the balance of excitation and inhibition in LSO is a primary cue used in the computation of interaural level differences, which are used to estimate sound source locations (Moore and Caspary, 1983; Kuwabara and Zook, 1992).

Many symptoms of FXS have been successfully modeled in Fmr1 KO mice. Fmr1 KO mice display auditory cortical hyperexcitability (Gibson et al., 2008; Rotschafer and Razak, 2013) and impaired synchronicity (Gibson et al., 2008; Hays et al., 2011; Lovelace et al., 2016). Behaviorally, Fmr1 KO mice exhibit audiogenic seizures (Musumeci et al., 2000, 2007; Chen and Toth, 2001), fail to habituate to sound (Lovelace et al., 2016), and fail to attenuate acoustic startle (Chen and Toth, 2001; Nielsen et al., 2002; Frankland et al., 2004). FMRP is prominently expressed in the auditory brainstem nuclei (Beebe et al., 2014; Wang et al., 2014; Zorio et al., 2017), and Fmr1 KO mice have anatomic and physiologic anomalies within the auditory brainstem (Kulesza and Mangunay, 2008; Kulesza et al., 2011; Lukose et al., 2011). Adult Fmr1 KO mice have heightened auditory brainstem response (ABR) thresholds, indicating a modest peripheral hearing loss (Rotschafer et al., 2015). In Fmr1 KO mice, there is an imbalance of excitatory and inhibitory synaptic proteins in

Acknowledgments: The authors thank Anushka Ramnani and Alana Porat for assistance with data collection.

Correspondence should be addressed Karina S. Cramer, Department of Neurobiology and Behavior, University of California, Irvine, Irvine, CA 92697. Email: cramerk@uci.edu

DOI:http://dx.doi.org/10.1523/ENEURO.0264-17.2017

Copyright (C) 2017 Rotschafer and Cramer

This is an open-access article distributed under the terms of the Creative Commons Attribution 4.0 International license, which permits unrestricted use, distribution and reproduction in any medium provided that the original work is properly attributed. the brainstem, with a relative increase in inhibitory inputs to the MNTB and an increase in inputs to the LSO (Rotschafer et al., 2015; Garcia-Pino et al., 2017). Additionally, like their human counterparts (Kulesza and Mangunay, 2008), adult Fmr1 KO animals have smaller cells within their auditory brainstem nuclei (Rotschafer et al., 2015; Ruby et al., 2015).

The observed Fmr1 KO phenotypes in the auditory brainstem might result indirectly from reduced peripheral input. Alternatively, they could arise from loss of FMRP in the brainstem nuclei themselves. Here, we examined the developmental emergence of auditory brainstem phenotypes in Fmr1 KO mice. We found differences in cell size at early postnatal ages. In addition, we found that the imbalances in inhibitory and excitatory synaptic markers in MNTB were evident before hearing onset, and before synaptic increases in LSO were present.

FMRP is expressed in microglia and astrocytes (Gholizadeh et al., 2015), which drive aspects of neuronal dysfunction in FXS. We investigated the emergence of glia in the auditory brainstem. We found that microglia emerge normally in the auditory brainstem in Fmr1 KO mice. However, we found significantly more astrocytes in VCN and LSO in Fmr1 KO mice. Additionally, the number of astrocytes in LSO correlated with synaptic markers in Fmr1 KO mice. Together, these studies demonstrate that several of the auditory brainstem phenotypes in Fmr1 KO mice arise during early postnatal development, and suggest that FMRP acts at multiple points along the auditory pathway.

\section{MATERIALS AND METHODS}

\section{Animals}

In this study, we used seven postnatal day 1 (P1), eight P6, and fifteen P14 FVB strain wild-type mice, and five P1, fourteen P6, and sixteen P14 Fmr1 KO mice. To test for possible sex differences, we compared data from a subset of the P14 animals including seven female and eight male wild-type mice and nine female and seven male Fmr1 KO mice. All procedures were approved by the University of California-Irvine Institutional Animal Care and Use Committee.

\section{Immunofluorescence}

Mice were perfused transcardially with $4 \%$ paraformaldehyde (PFA) in PBS, and brains were dissected. Brainstems were fixed in PFA solution for $2 \mathrm{~h}$, then equilibrated in a $30 \%$ sucrose solution in PBS overnight. Brains were cryosectioned at $16 \mu \mathrm{m}$ in the coronal plane at the level of the auditory brainstem nuclei. Sections were mounted on chrome-alum glass slides in a 1-in-4 (P1) or 1-in-6 (P6 and $P 14)$ series. Mounted sections were then surrounded with a Pap Pen hydrophobic barrier and rinsed in PBS for 10 min. For antigen retrieval, sections were incubated with $0.1 \%$ SDS in PBS solution for $5 \mathrm{~min}$. Slides were rinsed three times in PBS, then incubated with either normal goat blocking solution ( $4 \%$ normal goat serum, $0.1 \%$ Triton $\mathrm{X}-100$ in PBS), or bovine serum albumin blocking solution (4\% bovine serum albumin, $0.4 \%$ Triton $\mathrm{X}-100$ in PBS) for $1 \mathrm{~h}$ in a humid chamber at room temperature. Bovine serum albumin blocking solution was used for synaptic 
marker immunolabeling, and normal goat blocking solution was used for immunolabeling of glial cells. Primary antibodies (see below) were applied, and slides were incubated overnight in a humid chamber. Slides were washed in PBS and incubated at room temperature for 1 $\mathrm{h}$ with appropriate Alexa Fluor (Invitrogen) secondary antibodies diluted 1:500. Slides were rinsed three times in PBS and coverslipped with Glycergel mounting medium (Dako C0563).

\section{Primary antibodies}

To detect excitatory synaptic input, we used a guinea pig polyclonal antibody that recognized vesicular glutamate transporter-2 protein (VGLUT2) diluted to 1:2500 (Millipore AB2251). This protein reliably labels calyces of Held and shows stable expression levels during postnatal development in rats (Billups, 2005). Inhibitory synaptic input was examined using a rabbit polyclonal antibody that recognized vesicular GABA transporter protein (VGAT), which is expressed in both GABAergic and glycinergic synaptic terminals (Dumoulin et al., 1999), at a dilution of 1:200 (Phosphosolutions 2100-VGAT). In addition, we performed immunofluorescence for synaptophysin 1 , a vesicular membrane protein present in both excitatory and inhibitory presynaptic terminals, to evaluate total synaptic input. We used a guinea pig polyclonal antibody at a 1:500 dilution (Synaptic Systems 101 004). To detect microglia, we used a rabbit polyclonal antibody (Wako 019-19741) generated against a synthetic peptide corresponding to the $\mathrm{C}$ terminus of ionized calciumbinding adaptor molecule-1 (Iba1) at a dilution of 1:500. To detect astrocytes, we used a mouse monoclonal antibody (Abcam ab56777) that recognizes aldehyde marker dehydrogenase 1 family L1 (ALDH1L1) at a dilution of $1: 200$.

\section{Fluorescent Nissl analysis}

To visualize cell bodies and brainstem nuclei, we performed fluorescent Nissl staining using the BrainStain Imaging Kit (Life Technologies B34650). Slides were rinsed in $0.2 \%$ Triton $X-100$ solution in PBS then incubated for $20 \mathrm{~min}$ at room temperature with NeuroTrace 530/615 red fluorescent Nissl stain diluted 1:300 in PBS. Slides were then rinsed three times with PBS and coverslipped in Glycergel mounting medium.

To evaluate brainstem nucleus metrics, VCN, MNTB, and LSO of fluorescent Nissl stained sections were imaged at $20 \times$ using a Zeiss Axioskop-2 microscope. To study cell size, $40 \times z$-stacks of VCN, medial MNTB, lateral MNTB, and LSO were generated. Ten cells were randomly selected from each image for measurement; only cells in which the nucleus was visible and with a cross-sectional area $>45 \mu \mathrm{m}^{2}$ were included in the analysis. For brainstem nucleus size, nuclei from both the right and left hemispheres were imaged, with a minimum of two sections imaged per brain. Nuclei were outlined and measured using AxioVision software. The number of neurons in each section within the outlined nucleus was counted using ImageJ cell counter using above inclusion criteria, and a mean number of cells per section was obtained.

\section{Synaptic protein analysis}

High magnification images $(63 \times)$ of regions within VCN, medial MNTB, lateral MNTB, and LSO of VGLUT- and VGAT-immunolabeled sections were acquired. Regions of interest (ROls) within each image were selected. ROI size for each brainstem nucleus was consistent across images: $\mathrm{VCN}=10138.8 \mu \mathrm{m}^{2}$, MNTB $=11799.3 \mu \mathrm{m}^{2}$, medial MNTB $=6899.5 \mu \mathrm{m}^{2}$, lateral MNTB $=11,799.3 \mu \mathrm{m}^{2}$, and LSO $=13,239.5 \mu \mathrm{m}^{2}$. The red (VGLUT) and green (VGAT) color channels for each ROI were separated, and the threshold of each channel was adjusted to highlight the immunopositive areas within each ROI. ImageJ was used to sum the area of all of the immunolabeled objects within an ROI. Fractional coverage was defined as the summed area of immunolabeling divided by the area of the ROI. To compare the relative amounts of VGLUT and VGAT, we defined a synaptic protein index (ISP) to describe each ROI, where $I_{S P}=\left(\right.$ VGLUT - VGAT)/(VGLUT + VGAT). I $I_{S P}$ values range between -1 and 1 , with negative values indicating relatively more VGAT, and higher positive values indicating relatively more VGLUT.

\section{Analysis of microglia and astrocytes}

Based on fluorescent Nissl staining, VCN, MNTB, and LSO were outlined using AxioVision software. The outlines of these nuclei were then superimposed on images of Iba1- or ALDH1L1-immunolabeled sections. The ImageJ cell counter function was used to quantify lba1- or ALDH1L1-positive cells. As both microglia and astrocytes are highly ramified, glia were counted only if the somata were present within a section.

\section{Statistical methods}

We used Sigma Stat and Sigma Plot software for our statistical analyses and graphing. We tested for differences between genotypes (wild-type or Fmr1 KO) and differences between ages (P1, P6, or P14) using two-way ANOVAs to analyze cell size, nucleus size, number of cells, synaptic protein expression, and number of glia. We also examined medial versus lateral differences in MNTB cell size. We performed separate two-way ANOVAs to test the effects of genotype (wild-type or Fmr1 KO) and location (medial or lateral MNTB). Statistics supporting data shown in all figures are summarized in Table 1. Pairwise comparisons were made using the Holm-Šídák test. Additional comparisons were made using Pearson correlations along with appropriate Bonferroni corrections to determine whether effects were similar in the three auditory brainstem nuclei examined and whether synaptic proteins were correlated with glial cell numbers.

\section{Results}

To evaluate developmental differences in the Fmr1 KO auditory brainstem, we studied wild-type and Fmr1 KO mice at P1, P6, and P14. P1 represents an age when VCN, MNTB, and LSO are present, but the inputs to each nucleus are not yet fully formed (Morest, 1968; Hoffpauir et al., 2006). At P6, an age before hearing onset, synaptic inputs are present in these nuclei and have begun to mature, and spontaneous activity is evident in the auditory brainstem (Hoffpauir et al., 2010; Holcomb et al., 
Table 1. Statistical analysis

\begin{tabular}{|c|c|c|c|c|c|}
\hline Figure & Test & Sample size $(n)$ & Test statistics & $p$ & Power $\alpha=0.050$ \\
\hline $1 B$ & $\begin{array}{l}\text { Two-way } \\
\text { ANOVA }\end{array}$ & $\begin{array}{l}\text { WT: } P 1=5, P 6=8, P 14=15 ; \mathrm{KO}: \\
\quad \mathrm{P} 1=5, \mathrm{P} 6=10, \mathrm{P} 14=16\end{array}$ & $\begin{array}{l}\text { Age } F=74.469 ; \text { genotype } F=2.714 \\
\quad \text { age } \times \text { genotype } F=1.251\end{array}$ & $\begin{array}{l}\text { Age } p<0.001 ; \text { genotype } p=0.105 \\
\quad \text { age } \times \text { genotype } p=0.294\end{array}$ & $\begin{array}{l}\text { Age } \alpha=1.000 \text {; genotype } \alpha=0.236 \\
\quad \text { age } \times \\
\quad \text { genotype } \alpha=0.085\end{array}$ \\
\hline $2 B$ & $\begin{array}{l}\text { Two-way } \\
\text { ANOVA }\end{array}$ & $\begin{array}{l}W T: P 1=7, P 6=8, P 14=10 ; \mathrm{KO}: \\
\quad P 1=5, P 6=9, P 14=10\end{array}$ & $\begin{array}{l}\text { Age } F=234.948 ; \text { genotype } F=56.277 \\
\quad \text { age } \times \text { genotype } F=3.471\end{array}$ & $\begin{array}{l}\text { Age } p<0.001 ; \text { genotype } p<0.001 \\
\text { age } \times \text { genotype } p=0.040\end{array}$ & $\begin{array}{l}\text { Age } \alpha=1.000 ; \text { genotype } \alpha=1.000 \\
\quad \text { age } \times \text { genotype } \alpha=0.460\end{array}$ \\
\hline $3 D$ & $\begin{array}{l}\text { Two-way } \\
\text { ANOVA }\end{array}$ & $\begin{array}{l}\mathrm{WT}: \mathrm{P} 1=5, \mathrm{P} 6=8, \mathrm{P} 14=15 ; \mathrm{KO}: \\
\mathrm{P} 1=5, \mathrm{P} 6=10, \mathrm{P} 14=16\end{array}$ & $\begin{array}{l}\text { Location } F=10.762 ; \text { genotype } \\
\qquad \begin{array}{l}F=240.432 ; \text { location } \times \text { genotype } \\
F=11.572\end{array}\end{array}$ & $\begin{array}{l}\text { Location } p<0.001 \text {; genotype } \\
\qquad \begin{array}{l}p<0.001 ; \text { location } \times \text { genotype } \\
p=0.040\end{array}\end{array}$ & $\begin{array}{l}\text { Location } \alpha=0.859 ; \text { genotype } \alpha=1.000 \\
\quad \text { location } \times \text { genotype } \alpha=0.887\end{array}$ \\
\hline $3 E$ & $\begin{array}{l}\text { Two-way } \\
\text { ANOVA }\end{array}$ & $\begin{array}{l}W T: P 1=5, P 6=8, P 14=15 ; \mathrm{KO}: \\
\quad P 1=5, P 6=10, P 14=16\end{array}$ & $\begin{array}{l}\text { Location } F=14.142 ; \text { genotype } \\
\qquad \begin{array}{l}F=39.594 ; \text { location } \times \text { genotype } \\
F=5.922\end{array}\end{array}$ & $\begin{array}{l}\text { Location } p<0.001 \text {; genotype } \\
\qquad \begin{array}{l}p<0.001 ; \text { location } \times \text { genotype } \\
p=0.020\end{array}\end{array}$ & $\begin{array}{l}\text { Location } \alpha=0.958 ; \text { genotype } \alpha=1.000 \\
\quad \text { location } \times \text { genotype } \alpha=0.577\end{array}$ \\
\hline $3 F$ & $\begin{array}{l}\text { Two-way } \\
\text { ANOVA }\end{array}$ & $\begin{array}{l}W T: P 1=5, P 6=8, P 14=15 ; \mathrm{KO}: \\
\quad \mathrm{P} 1=5, \mathrm{P} 6=10, \mathrm{P} 14=16\end{array}$ & $\begin{array}{l}\text { Location } F=144.012 ; \text { genotype } \\
\qquad \begin{array}{l}F=36.820 ; \text { location } \times \text { genotype } \\
F=1.056\end{array}\end{array}$ & $\begin{array}{l}\text { Location } p<0.001 \text {; genotype } \\
\qquad \begin{array}{l}p<0.001 \text {; location } \times \text { genotype } \\
p=0.308\end{array}\end{array}$ & $\begin{array}{l}\text { Location } \alpha=1.000 ; \text { genotype } \alpha=1.000 \\
\quad \text { location } \times \text { genotype } \alpha=0.053\end{array}$ \\
\hline $4 B$ & $\begin{array}{l}\text { Two-way } \\
\text { ANOVA }\end{array}$ & $\begin{array}{l}W T: P 1=7, P 6=8, P 14=10 ; \mathrm{KO}: \\
\quad P 1=5, P 6=9, P 14=10\end{array}$ & $\begin{array}{l}\text { Age } F=30.240 ; \text { genotype } F=48.714 \\
\text { age } \times \text { genotype } F=2.404\end{array}$ & $\begin{array}{l}\text { Age } p<0.001 ; \text { genotype } p<0.001 \\
\text { age } \times \text { genotype } p=0.100\end{array}$ & $\begin{array}{l}\text { Age } \alpha=1.000 ; \text { genotype } \alpha=1.000 \\
\quad \text { age } \times \text { genotype } \alpha=0.278\end{array}$ \\
\hline $5 B$ & $\begin{array}{l}\text { Two-way } \\
\text { ANOVA }\end{array}$ & $\begin{array}{c}W T: P 1=5, P 6=8, P 14=15 ; K O: \\
P 1=5, P 6=10, P 14=16\end{array}$ & $\begin{array}{l}\text { Age } F=74.602 ; \text { genotype } F=1.300 \\
\quad \text { age } \times \text { genotype } F=0.839\end{array}$ & $\begin{array}{l}\text { Age } p<0.001 ; \text { genotype } p=0.259 \\
\text { age } \times \text { genotype } p=0.438\end{array}$ & $\begin{array}{l}\text { Age } \alpha=1.000 ; \text { genotype } \alpha=0.0789 \\
\quad \text { age } \times \text { genotype } \alpha=0.050\end{array}$ \\
\hline $5 C$ & $\begin{array}{l}\text { Two-way } \\
\text { ANOVA }\end{array}$ & $\begin{array}{l}W T: P 1=5, P 6=8, P 14=15 ; K O: \\
P 1=5, P 6=10, P 14=16\end{array}$ & $\begin{array}{l}\text { Age } F=6.544 ; \text { genotype } F=0.049 \\
\quad \text { age } \times \text { genotype } F=0.730\end{array}$ & $\begin{array}{l}\text { Age } p=0.003 ; \text { genotype } p=0.824 \\
\quad \text { age } \times \text { genotype } p=0.487\end{array}$ & $\begin{array}{l}\text { Age } \alpha=0.844 ; \text { genotype } \alpha=0.050 \\
\quad \text { age } \times \text { genotype } \alpha=0.050\end{array}$ \\
\hline $5 E$ & $\begin{array}{l}\text { Two-way } \\
\text { ANOVA }\end{array}$ & $\begin{array}{l}W T: P 1=5, P 6=8, P 14=15 ; K O: \\
P 1=5, P 6=10, P 14=16\end{array}$ & $\begin{array}{l}\text { Age } F=188.708 ; \text { genotype } F=1.683 \\
\text { age } \times \text { genotype } F=0.860\end{array}$ & $\begin{array}{l}\text { Age } p<0.001 ; \text { genotype } p=0.200 \\
\text { age } \times \text { genotype } p=0.428\end{array}$ & $\begin{array}{l}\text { Age } \alpha=1.000 ; \text { genotype } \alpha=0.120 \\
\quad \text { age } \times \text { genotype } \alpha=0.050\end{array}$ \\
\hline $5 F$ & $\begin{array}{l}\text { Two-way } \\
\text { ANOVA }\end{array}$ & $\begin{array}{l}W T: P 1=5, P 6=8, P 14=15 ; K O: \\
P 1=5, P 6=10, P 14=16\end{array}$ & $\begin{array}{l}\text { Age } F=28.024 ; \text { genotype } F=0.009 \\
\quad \text { age } \times \text { genotype } F=0.473\end{array}$ & $\begin{array}{l}\text { Age } p<0.001 ; \text { genotype } p=0.925 \\
\text { age } \times \text { genotype } p=0.626\end{array}$ & $\begin{array}{l}\text { Age } \alpha=1.000 ; \text { genotype } \alpha=0.050 \\
\quad \text { age } \times \text { genotype } \alpha=0.050\end{array}$ \\
\hline $5 H$ & $\begin{array}{l}\text { Two-way } \\
\text { ANOVA }\end{array}$ & $\begin{array}{l}\mathrm{WT}: \mathrm{P} 1=5, \mathrm{P} 6=8, \mathrm{P} 14=15 ; \mathrm{KO}: \\
\mathrm{P} 1=5, \mathrm{P} 6=10, \mathrm{P} 14=16\end{array}$ & $\begin{array}{l}\text { Age } F=60.344 ; \text { genotype } F=0.792 \\
\quad \text { age } \times \text { genotype } F=0.155\end{array}$ & $\begin{array}{l}\text { Age } p<0.001 ; \text { genotype } p=0.377 \\
\quad \text { age } \times \text { genotype } p=0.857\end{array}$ & $\begin{array}{l}\text { Age } \alpha=1.000 ; \text { genotype } \alpha=0.050 \\
\quad \text { age } \times \text { genotype } \alpha=0.050\end{array}$ \\
\hline $5 /$ & $\begin{array}{l}\text { Two-way } \\
\text { ANOVA }\end{array}$ & $\begin{array}{l}W T: P 1=5, P 6=8, P 14=15 ; K O: \\
P 1=5, P 6=10, P 14=16\end{array}$ & $\begin{array}{l}\text { Age } F=35.620 ; \text { genotype } F=0.724 \\
\quad \text { age } \times \text { genotype } F=0.620\end{array}$ & $\begin{array}{l}\text { Age } p<0.001 ; \text { genotype } p=0.398 \\
\quad \text { age } \times \text { genotype } p=0.541\end{array}$ & $\begin{array}{l}\text { Age } \alpha=1.000 ; \text { genotype } \alpha=0.050 \\
\text { age } \times \text { genotype } \alpha=0.050\end{array}$ \\
\hline $6 D$ & $\begin{array}{l}\text { Two-way } \\
\text { ANOVA }\end{array}$ & $\begin{array}{l}W T: P 6=7, P 14=10 ; \mathrm{KO}: \\
P 6=13, \mathrm{P} 14=16\end{array}$ & $\begin{array}{l}\text { Age } F=30.666 ; \text { genotype } F=0.009 \\
\quad \text { age } \times \text { genotype } F=0.002\end{array}$ & $\begin{array}{l}\text { Age } p<0.001 ; \text { genotype } p=0.926 \\
\text { age } \times \text { genotype } p=0.967\end{array}$ & $\begin{array}{l}\text { Age } \alpha=1.000 ; \text { genotype } \alpha=0.050 \\
\quad \text { age } \times \text { genotype } \alpha=0.050\end{array}$ \\
\hline $6 E$ & $\begin{array}{l}\text { Two-way } \\
\text { ANOVA }\end{array}$ & $\begin{array}{l}W T: P 6=7, P 14=10 ; \mathrm{KO} \\
P 6=13, \mathrm{P} 14=16\end{array}$ & $\begin{array}{l}\text { Age } F=10.846 ; \text { genotype } F=0.098 \\
\quad \text { age } \times \text { genotype } F=0.078\end{array}$ & $\begin{array}{l}\text { Age } p=0.002 ; \text { genotype } p=0.756 \\
\quad \text { age } \times \text { genotype } p=0.782\end{array}$ & $\begin{array}{l}\text { Age } \alpha=0.883 ; \text { genotype } \alpha=0.050 \\
\quad \text { age } \times \text { genotype } \alpha=0.050\end{array}$ \\
\hline $6 F$ & $\begin{array}{l}\text { Two-way } \\
\text { ANOVA }\end{array}$ & $\begin{array}{l}W T: P 6=7, P 14=10 ; K O: \\
P 6=13, P 14=16\end{array}$ & $\begin{array}{l}\text { Age } F=1.350 ; \text { genotype } F=3.178 \\
\text { age } \times \text { genotype } F=0.008\end{array}$ & $\begin{array}{l}\text { Age } p=0.255 ; \text { genotype } p=0.085 \\
\text { age } \times \text { genotype } p=0.927\end{array}$ & $\begin{array}{l}\text { Age } \alpha=0.083 ; \text { genotype } \alpha=0.282 \\
\quad \text { age } \times \text { genotype } \alpha=0.050\end{array}$ \\
\hline $6 G$ & $\begin{array}{l}\text { Two-way } \\
\text { ANOVA }\end{array}$ & $\begin{array}{l}W T: P 6=7, P 14=10 ; \mathrm{KO}: \\
P 6=13, \mathrm{P} 14=16\end{array}$ & $\begin{array}{l}\text { Age } F=15.330 ; \text { genotype } F=0.195 \\
\quad \text { age } \times \text { genotype } F=0.094\end{array}$ & $\begin{array}{l}\text { Age } p<0.001 ; \text { genotype } p=0.661 \\
\text { age } \times \text { genotype } p=0.760\end{array}$ & $\begin{array}{l}\text { Age } \alpha=0.972 ; \text { genotype } \alpha=0.050 \\
\quad \text { age } \times \text { genotype } \alpha=0.050\end{array}$ \\
\hline $7 D$ & $\begin{array}{l}\text { Two-way } \\
\text { ANOVA }\end{array}$ & $\begin{array}{l}W T: P 6=8, P 14=10 ; K O \\
P 6=13, P 14=16\end{array}$ & $\begin{array}{l}\text { Age } F=0.283 ; \text { genotype } F=0.417 \\
\quad \text { age } \times \text { genotype } F=1.336\end{array}$ & $\begin{array}{l}\text { Age } p=0.600 ; \text { genotype } p=0.525 \\
\quad \text { age } \times \text { genotype } p=0.260\end{array}$ & $\begin{array}{l}\text { Age } \alpha=0.050 ; \text { genotype } \alpha=0.050 \\
\quad \text { age } \times \text { genotype } \alpha=0.081\end{array}$ \\
\hline $7 E$ & $\begin{array}{l}\text { Two-way } \\
\text { ANOVA }\end{array}$ & $\begin{array}{l}W T: P 6=8, P 14=10 ; K O: \\
P 6=13, P 14=16\end{array}$ & $\begin{array}{l}\text { Age } F=0.804 ; \text { genotype } F=66.730 \\
\quad \text { age } \times \text { genotype } F=0.017\end{array}$ & $\begin{array}{l}\text { Age } p=0.379 ; \text { genotype } p<0.001 \\
\quad \text { age } \times \text { genotype } p=0.896\end{array}$ & $\begin{array}{l}\text { Age } \alpha=0.050 ; \text { genotype } \alpha=1.000 \\
\quad \text { age } \times \text { genotype } \alpha=0.050\end{array}$ \\
\hline $7 F$ & $\begin{array}{l}\text { Two-way } \\
\text { ANOVA }\end{array}$ & $\begin{array}{l}W T: P 6=8, P 14=10 ; K O: \\
P 6=13, P 14=16\end{array}$ & $\begin{array}{l}\text { Age } F=1.785 ; \text { genotype } F=4.347 \\
\text { age } \times \text { genotype } F=0.037\end{array}$ & $\begin{array}{l}\text { Age } p=0.194 ; \text { genotype } p=0.047 \\
\quad \text { age } \times \text { genotype } p=0.849\end{array}$ & $\begin{array}{l}\text { Age } \alpha=0.128 ; \text { genotype } \alpha=0.408 \\
\quad \text { age } \times \text { genotype } \alpha=0.050\end{array}$ \\
\hline $7 G$ & $\begin{array}{l}\text { Two-way } \\
\text { ANOVA }\end{array}$ & $\begin{array}{l}W T: P 6=8, P 14=10 ; K O: \\
P 6=13, P 14=16\end{array}$ & $\begin{array}{l}\text { Age } F=1.291 ; \text { genotype } F=23.979 \\
\quad \text { age } \times \text { genotype } F=0.719\end{array}$ & $\begin{array}{l}\text { Age } p=0.268 ; \text { genotype } p<0.001 \\
\quad \text { age } \times \text { genotype } p=0.406\end{array}$ & $\begin{array}{l}\text { Age } \alpha=0.077 ; \text { genotype } \alpha=0.998 \\
\quad \text { age } \times \text { genotype } \alpha=0.050\end{array}$ \\
\hline $8 D$ & $\begin{array}{l}\text { Two-way } \\
\text { ANOVA }\end{array}$ & $\begin{array}{l}W T: P 6=8, P 14=10 ; K O \\
P 6=13, P 14=16\end{array}$ & $\begin{array}{l}\text { Age } F=16.857 ; \text { genotype } F=0.210 \\
\quad \text { age } \times \text { genotype } F=0.169\end{array}$ & $\begin{array}{c}\text { Age } p<0.001 ; \text { genotype } p=0.649 \\
\text { age } \times \text { genotype } p=0.683\end{array}$ & $\begin{array}{l}\text { Age } \alpha=0.984 ; \text { genotype } \alpha=0.050 \\
\quad \text { age } \times \text { genotype } \alpha=0.050\end{array}$ \\
\hline $8 E$ & $\begin{array}{l}\text { Two-way } \\
\text { ANOVA }\end{array}$ & $\begin{array}{l}W T: P 6=8, P 14=10 ; K O: \\
P 6=13, P 14=16\end{array}$ & $\begin{array}{l}\text { Age } F=13.242 ; \text { genotype } F=0.991 \\
\quad \text { age } \times \text { genotype } F=0.078\end{array}$ & $\begin{array}{l}\text { Age } p<0.001 ; \text { genotype } p=0.325 \\
\text { age } \times \text { genotype } p=0.782\end{array}$ & $\begin{array}{l}\text { Age } \alpha=0.944 ; \text { genotype } \alpha=0.050 \\
\quad \text { age } \times \text { genotype } \alpha=0.050\end{array}$ \\
\hline $8 F$ & $\begin{array}{l}\text { Two-way } \\
\text { ANOVA }\end{array}$ & $\begin{array}{l}W T: P 6=8, P 14=10 ; K O: \\
P 6=13, P 14=16\end{array}$ & $\begin{array}{l}\text { Age } F=5.388 ; \text { genotype } F=40.622 \\
\quad \text { age } \times \text { genotype } F=0.008\end{array}$ & $\begin{array}{l}\text { Age } p<0.001 ; \text { genotype } p=0.027 ; \text { a } \\
\text { ge } \times \text { genotype } p=0.929\end{array}$ & $\begin{array}{l}\text { Age } \alpha=1.000 ; \text { genotype } \alpha=0.519 \\
\quad \text { age } \times \text { genotype } \alpha=0.050\end{array}$ \\
\hline $8 G$ & $\begin{array}{l}\text { Two-way } \\
\text { ANOVA }\end{array}$ & $\begin{array}{l}W T: P 6=8, P 14=10 ; K O \\
P 6=13, P 14=16\end{array}$ & $\begin{array}{l}\text { Age } F=62.677 ; \text { genotype } F=4.302 \\
\quad \text { age } \times \text { genotype } F=1.233\end{array}$ & $\begin{array}{l}\text { Age } p<0.001 ; \text { genotype } p=0.044 \\
\text { age } \times \text { genotype } p=0.273\end{array}$ & $\begin{array}{l}\text { Age } \alpha=1.000 ; \text { genotype } \alpha=0.414 \\
\quad \text { age } \times \text { genotype } \alpha=0.072\end{array}$ \\
\hline $9 D$ & $\begin{array}{l}\text { Two-way } \\
\text { ANOVA }\end{array}$ & $\begin{array}{c}W T: P 1=7, P 6=8, P 14=15 ; \mathrm{KO}: \\
\mathrm{P} 1=5, \mathrm{P} 6=14, \mathrm{P} 14=16\end{array}$ & $\begin{array}{l}\text { Age } F=24.955 ; \text { genotype } F=1.250 \\
\quad \text { age } \times \text { genotype } F=0.125\end{array}$ & $\begin{array}{l}\text { Age } p<0.001 ; \text { genotype } p=0.269 \\
\text { age } \times \text { genotype } p=0.882\end{array}$ & $\begin{array}{l}\text { Age } \alpha=1.000 ; \text { genotype } \alpha=0.074 \\
\quad \text { age } \times \text { genotype } \alpha=0.050\end{array}$ \\
\hline $9 H$ & $\begin{array}{l}\text { Two-way } \\
\text { ANOVA }\end{array}$ & $\begin{array}{c}W T: P 1=7, P 6=8, P 14=15 ; K O: \\
P 1=5, P 6=14, P 14=16\end{array}$ & $\begin{array}{l}\text { Age } F=52.928 ; \text { genotype } F=0.219 \\
\quad \text { age } \times \text { genotype } F=0.428\end{array}$ & $\begin{array}{l}\text { Age } p<0.001 ; \text { genotype } p=0.642 \\
\text { age } \times \text { genotype } p=0.654\end{array}$ & $\begin{array}{l}\text { Age } \alpha=1.000 ; \text { genotype } \alpha=0.050 \\
\quad ; \text { age } \times \text { genotype } \alpha=0.050\end{array}$ \\
\hline $9 L$ & $\begin{array}{l}\text { Two-way } \\
\text { ANOVA }\end{array}$ & $\begin{array}{l}W T: P 1=7, P 6=8, P 14=15 ; \mathrm{KO}: \\
\quad \mathrm{P} 1=5, \mathrm{P} 6=14, \mathrm{P} 14=16\end{array}$ & $\begin{array}{l}\text { Age } F=50.641 ; \text { genotype } F=0.783 \\
\quad \text { age } \times \text { genotype } F=1.917\end{array}$ & $\begin{array}{l}\text { Age } p<0.001 ; \text { genotype } p=0.380 \\
\quad \text { age } \times \text { genotype } p=0.156\end{array}$ & $\begin{array}{l}\text { Age } \alpha=1.000 ; \text { genotype } \alpha=0.050 \\
\quad \text { age } \times \text { genotype } \alpha=0.193\end{array}$ \\
\hline $10 B$ & $\begin{array}{l}\text { Two-way } \\
\text { ANOVA }\end{array}$ & $\begin{array}{c}W T: P 6=8, P 14=13 ; \mathrm{KO}: \\
P 6=10, \mathrm{P} 14=11\end{array}$ & $\begin{array}{l}\text { Age } F=21.766 ; \text { genotype } F=5.393 \\
\quad \text { age } \times \text { genotype } F=1.687\end{array}$ & $\begin{array}{l}\text { Age } p<0.001 ; \text { genotype } p=0.026 \\
\text { age } \times \text { genotype } p=0.203\end{array}$ & $\begin{array}{l}\text { Age } \alpha=0.997 ; \text { genotype } \alpha=0.524 \\
\text { age } \times \text { genotype } \alpha=0.119\end{array}$ \\
\hline $10 D$ & $\begin{array}{l}\text { Two-way } \\
\text { ANOVA }\end{array}$ & $\begin{array}{c}W T: P 6=8, P 14=13 ; \mathrm{KO}: \\
P 6=10, \mathrm{P} 14=11\end{array}$ & $\begin{array}{l}\text { Age } F=19.654 ; \text { genotype } F=1.462 \\
\quad \text { age } \times \text { genotype } F=0.256\end{array}$ & $\begin{array}{l}\text { Age } p<0.001 ; \text { genotype } p=0.234 \\
\text { age } \times \text { genotype } p=0.616\end{array}$ & $\begin{array}{l}\text { Age } \alpha=0.994 ; \text { genotype } \alpha=0.095 \\
\quad \text { age } \times \text { genotype } \alpha=0.050\end{array}$ \\
\hline $10 F$ & $\begin{array}{l}\text { Two-way } \\
\text { ANOVA }\end{array}$ & $\begin{array}{l}W T: P 6=8, P 14=13 ; \mathrm{KO}: \\
\quad P 6=10, \mathrm{P} 14=11\end{array}$ & $\begin{array}{l}\text { Age } F=27.231 ; \text { genotype } F=5.368 \\
\quad \text { age } \times \text { genotype } F=2.468\end{array}$ & $\begin{array}{l}\text { Age } p<0.001 ; \text { genotype } p=0.026 \\
\text { age } \times \text { genotype } p=0.125\end{array}$ & $\begin{array}{l}\text { Age } \alpha=1.000 ; \text { genotype } \alpha=0.523 \\
\quad \text { age } \times \text { genotype } \alpha=0.205\end{array}$ \\
\hline
\end{tabular}

2013; Wang and Bergles, 2015). By P14, just after hearing onset, inputs to nuclei have undergone considerable pruning (Hoffpauir et al., 2006). Here, we analyze the genesis of the cellular and synaptic abnormalities found in adult Fmr1 $\mathrm{KO}$ mice to investigate the emergence of adult Fmr1 KO auditory brainstem phenotypes.

\section{Cell size is significantly reduced in Fmr1 KO auditory brainstem nuclei}

Previous studies have shown that cell sizes in the auditory brainstem nuclei of adult Fmr1 KO animals were significantly reduced in VCN and in MNTB, but not in LSO (Rotschafer et al., 2015; Ruby et al., 2015). Here, 
we investigated the developmental emergence of this phenotype. We compared cell size by genotype and age within VCN, MNTB, and LSO. As MNTB is known to have a medial-lateral cell size gradient (Pasic and Rubel, 1991; Weatherstone et al., 2017), we also analyzed the medial and lateral portions of MNTB separately then assessed the development of the gradient by comparing the size of cells in the medial to those in the lateral MNTB.

\section{VCN}

We examined VCN cell size in fluorescent Nissl sections at P1, P6, and P14 (Fig. 1A). We did not observe a significant difference in cell size between wild-type and $F m r 1 \mathrm{KO}$ at $\mathrm{P} 1, \mathrm{P} 6$, or $\mathrm{P} 14\left(F_{1,60}=2.714, p=\right.$ 0.105 ; Fig. $1 B$ ), although cells got larger with age in both genotypes $\left(F_{2,60}=74.469, p<0.001\right)$. No interaction was seen between the effects of genotype and age. The mean cell size for wild-type mice was $101.9 \pm$ $3.0 \mu \mathrm{m}^{2}$ at P1, $118.9 \pm 7.4 \mu \mathrm{m}^{2}$ at P6, and $193.8 \pm 5.1$ $\mu \mathrm{m}^{2}$ at $\mathrm{P} 14$. In Fmr1 $\mathrm{KO}$ mice, the mean cell size was $94.4 \pm 5.3 \mu \mathrm{m}^{2}$ at $\mathrm{P} 1,116.9 \pm 8.3 \mu \mathrm{m}^{2}$ at $\mathrm{P} 6$, and 171.5 $\pm 7.0 \mu \mathrm{m}^{2}$ at P14 (Fig. 1A). These data suggest that the adult-like phenotype of reduced VCN cell size is evident only after hearing onset.

\section{MNTB}

Fmr1 KO MNTB cells were significantly smaller than wild-type MNTB cells at all ages tested (Fig. 2A, B). Both wild-type and $F m r 1$ KO MNTB cells significantly increased in size with age $\left(F_{2,43}=234.948, p<0.001\right)$. Cells were significantly smaller in Fmr1 KO MNTB $\left(F_{2,43}=56.277, p\right.$ $<0.001)$. The mean cross-sectional area of wild-type MNTB cells was $108.2 \pm 3.5 \mu \mathrm{m}^{2}$ at $\mathrm{P} 1,113.2 \pm 2.6 \mu \mathrm{m}^{2}$ at P6, and $204.9 \pm 6.3 \mu \mathrm{m}^{2}$ at P14. In contrast, the mean cross-sectional area of MNTB cells in Fmr1 KO mice was $63.9 \pm 3.9 \mu \mathrm{m}^{2}$ at $\mathrm{P} 1,96.8 \pm 3.6 \mu \mathrm{m}^{2}$ at P6, and $166.5 \pm$ $5.9 \mu \mathrm{m}^{2}$ at P14. No significant interactions were seen between age and genotype.

Because FMRP is expressed along a medial-lateral gradient in MNTB (Ruby et al., 2015) we tested whether FMRP deletion impairs the development of the cell size gradient found in MNTB (Weatherstone et al., 2017). We examined cell size in medial and lateral portions of wildtype and Fmr1 KO mice in MNTB at P1 (Fig. 3A), P6 (Fig. $3 B$ ), and P14 (Fig. $3 C$ ). We found that cell size at P1 was significantly different between genotypes $\left(F_{1,20}=\right.$ 240.432, $p<0.001)$ and locations $\left(F_{1,20}=10.762, p=\right.$ 0.004; Fig. 3D). Although cells in the medial portion of the MNTB in wild-type mice were significantly smaller than those in the lateral portion, there was no medial versus lateral difference in Fmr1 KO mice (Figs. 3D) at this age. Similarly, at P6 (Fig. 3E) cell size was significantly different between genotypes $\left(F_{1,40}=39.594, p<0.001\right)$ and locations $\left(F_{1,40}=14.142, p<0.001\right)$. Medial and lateral MNTB cell sizes were significantly different in wild-type mice, but not different in Fmr1 KO mice. An interaction between location and genotype was seen at P1 and P6. At P14 (Fig. $3 F)$, cell size by both genotype $\left(F_{1,58}=36.820, p<\right.$ $0.001)$ and cell location $\left(F_{1,58}=144.012, p<0.001\right)$ was significantly different, but no interaction was observed at this age. In the medial portion of MNTB, wild-type cells were $112.6 \pm 3.5 \mu \mathrm{m}^{2}$ at $\mathrm{P} 1,106.8 \pm 1.5 \mu \mathrm{m}^{2}$ at $\mathrm{P} 6$, and $131.1 \pm 2.7 \mu \mathrm{m}^{2}$ at $\mathrm{P} 14$. In Fmr1 KO medial MNTB, cells were $69.3 \pm 4.4 \mu \mathrm{m}^{2}$ at $\mathrm{P} 1,89.5 \pm 3.6 \mu \mathrm{m}^{2}$ at $\mathrm{P} 6$, and $98.9 \pm 2.3 \mu \mathrm{m}^{2}$ at P14. In wild-type mice, lateral MNTB cells were $136.5 \pm 3.3 \mu \mathrm{m}^{2}$ at $\mathrm{P} 1,134.6 \pm 5.1 \mu \mathrm{m}^{2}$ at $\mathrm{P} 6$, and $214.3 \pm 8.4 \mu \mathrm{m}^{2}$ at $\mathrm{P} 14$. In Fmr1 $\mathrm{KO}$ mice, lateral MNTB cells were $68.8 \pm 2.6 \mu \mathrm{m}^{2}$ at $\mathrm{P} 1,95.5 \pm 4.9 \mu \mathrm{m}^{2}$ at $\mathrm{P} 6$, and $169.0 \pm 8.9 \mu \mathrm{m}^{2}$ at P14. Thus, while MNTB cells were smaller in Fmr1 KO mice throughout the nucleus at all ages tested, we found that a gradient of cell size emerged early in wild-type mice and was evident by P14 in both Fmr1 $\mathrm{KO}$ and wild-type mice.

\section{LSO}

We found that Fmr1 deletion was associated with reduced cell size in LSO (Fig. 4A). In wild-type mice, the mean cross-sectional area of LSO cells was $132.4 \pm 8.0$ $\mu \mathrm{m}^{2}$ at $\mathrm{P} 1,118.7 \pm 3.1 \mu \mathrm{m}^{2}$ at $\mathrm{P} 6$, and $156.0 \pm 5.7 \mu \mathrm{m}^{2}$ at P14. In Fmr1 KO mice, LSO cells measured $85.9 \pm 5.9$ $\mu \mathrm{m}^{2}$ at $\mathrm{P} 1,98.8 \pm 1.5 \mu \mathrm{m}^{2}$ at $\mathrm{P} 6$, and $127.4 \pm 4.4 \mu \mathrm{m}^{2}$ at $\mathrm{P} 14$. Cell size in $F m r 1 \mathrm{KO}$ mice was significantly smaller than that seen in wild-type mice at P1, P6, and P14 $\left(F_{1,56}\right.$ $=48.714, p<0.001$; Fig. $4 B$ ). Significant differences in LSO cell size were also found with age $\left(F_{2,56}=30.240, p\right.$ $<0.001$ ) for wild-type and Fmr1 KO mice (Fig. 4B). Cell size increased at each age in Fmr1 KO mice. Thus, whereas adult Fmr1 KO mice show normal cell size in LSO, a developmental delay in the growth of these cells is observed in these mutants.

\section{Correlation of cell size across nuclei}

Because cell size reduction was a prominent phenotype in all three nuclei, we tested whether cell size was correlated between nuclei in individual animals. We obtained Pearson correlations among the three nuclei separately for mutant and wild-type animals and for both ages. After Bonferroni correction, we did not find significant correlations at for either genotype at P6. We found that cell size in VCN was positively correlated with cell size in LSO in P14 Fmr1 KO mice $(p<0.002)$, but the correlation between VCN and LSO in P14 wild-type mice did not reach significance after correction. The statistics are shown in Table 2.

\section{Similar auditory nucleus size and number of cells in wild-type and Fmr1 KO mice VCN}

A two-way ANOVA showed that age (P1, P6, or P14) had a significant effect on nucleus size $\left(F_{2,53}=74.602, p\right.$ $<0.001$ ), but genotype (wild-type or Fmr1 KO) did not $\left(F_{1,53}=1.300, p=0.259\right)$. Pairwise analysis showed that VCN grew at a consistent rate in both wild-type and Fmr1 $\mathrm{KO}$ mice (Fig. $5 A, B$ ). In wild-type mice, the mean area of VCN sections was $70,136 \pm 5327 \mu \mathrm{m}^{2}$ at $\mathrm{P} 1,165,628 \pm$ $14,272 \mu \mathrm{m}^{2}$ at P6, and $182,174 \pm 5247 \mu \mathrm{m}^{2}$ at P14. In Fmr1 KO mice, the mean area of VCN was $71,729 \pm 3160$ $\mu \mathrm{m}^{2}$ at $\mathrm{P} 1,144,924 \pm 5928 \mu \mathrm{m}^{2}$ at $\mathrm{P} 6$, and 177,055 \pm $6652 \mu \mathrm{m}^{2}$ at P14. As in wild-type mice, the number of cells in VCN at different ages increased significantly $\left(F_{2,53}=6.544\right.$, 

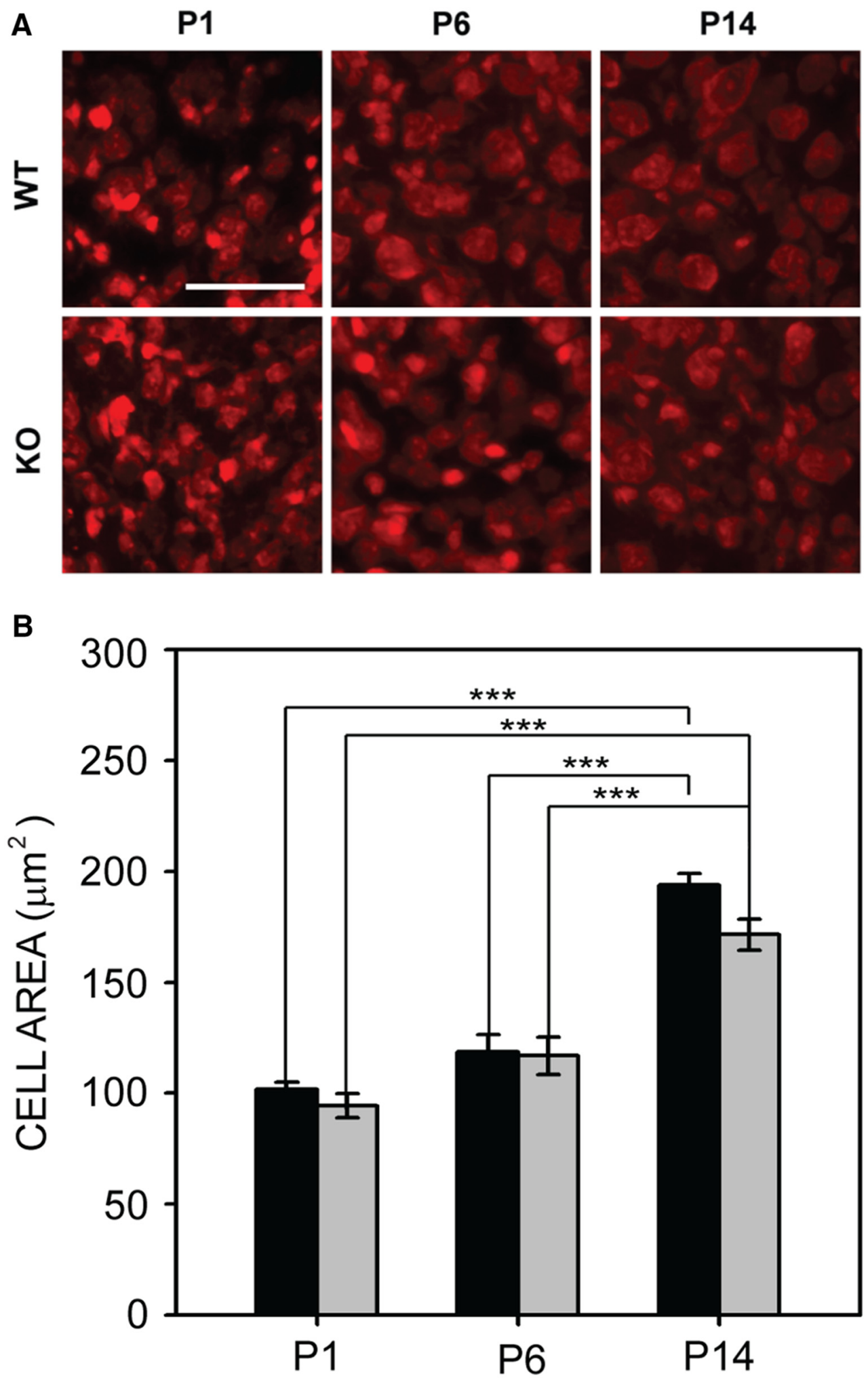

Figure 1. VCN cell size in wild-type and Fmr1 KO mice. A, VCN cells stained with fluorescent Nissl in wild-type (top) and Fmr1 KO (bottom) mice at P1, P6, and P14. Scale bar $=100 \mu \mathrm{m}$. B, Cell size did not differ between wild-type mice (black bars) and Fmr1 KO mice (gray bars) at P1, P6, or P14. Both genotypes showed increases in cell size between P1 and P14, and between P6 and P14. *, $p<0.05 ; * *, p<0.01 ;$ and $* * *, p<0.001$. 

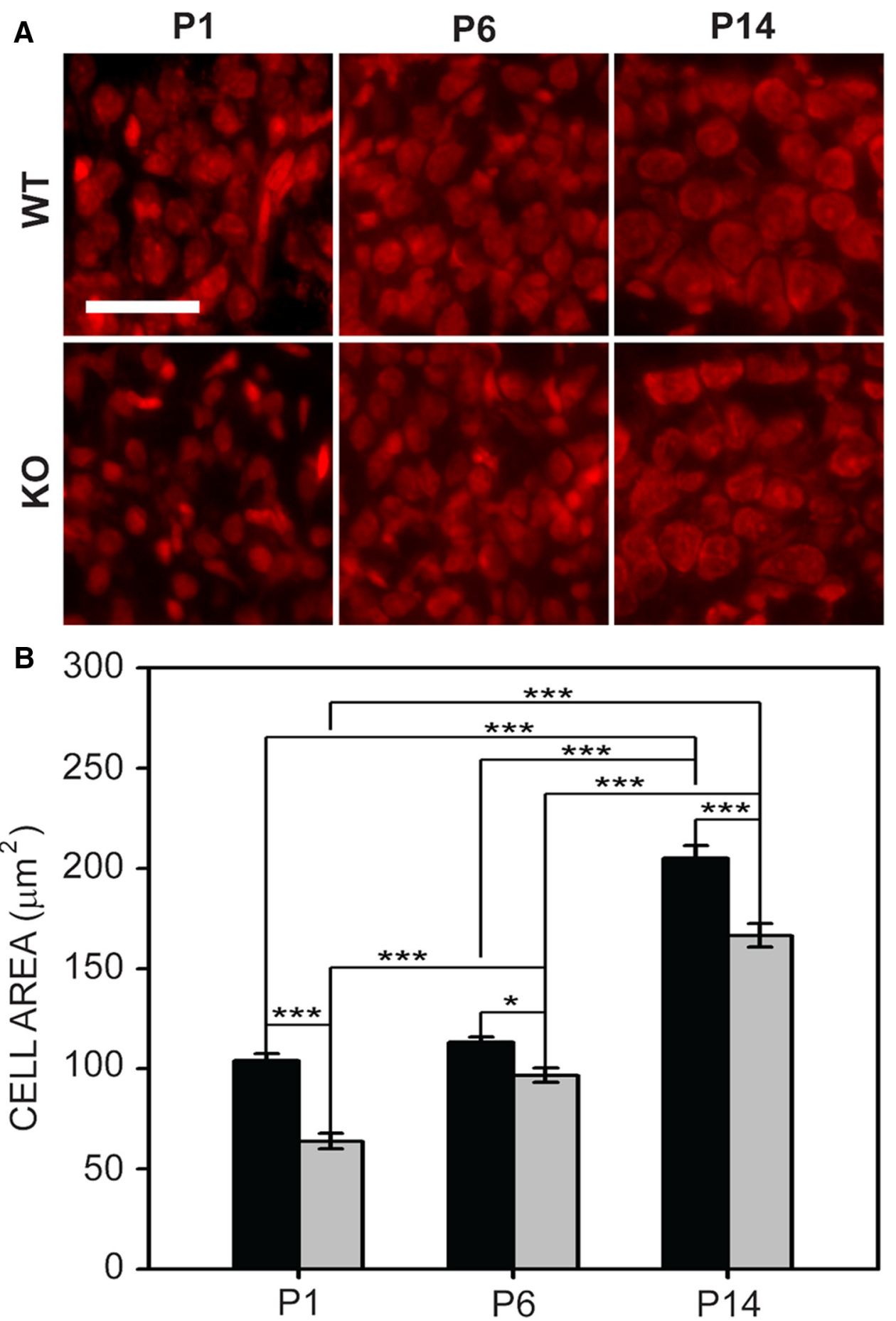

Figure 2. MNTB cell size in wild-type and Fmr1 KO mice. A, MNTB cells in wild-type mice (top) and Fmr1 KO mice (bottom) at P1, P6, and P14. Scale bar $=100 \mu \mathrm{m}$. B , The cross-sectional area of $F m r 1 \mathrm{KO}$ neurons was significantly reduced compared to wild-type mice at all ages tested. $*, p<0.05 ; * *, p<0.01$; and $* * *, p<0.001$.

$p=0.003)$. Wild-type mice gained cells in VCN from P1 $(445.6 \pm 23.2$ cells) to P6 (587.2 \pm 24.4 cells), but not from P6 to P14 (581.1 \pm 19.7 cells). VCN in Fmr1 KO mice also showed a significant gain in cell numbers between $\mathrm{P} 1$ $(484.8 \pm 38.9$ cells $)$ and P6 $(545.4 \pm 40.1)$, and between P6 and P14 (567.2 \pm 18.2 cells). Both Fmr1 KO and wild-type mice showed a significant increase in cell number between P1 and P14 (Fig. 5C).

\section{MNTB}

Analysis of MNTB also showed significant differences in nucleus size with age $\left(F_{2,59}=188.708, p<0.001\right)$, but not with genotype $\left(F_{1,59}=1.683, p=0.200\right.$; Fig. $\left.5 D\right)$. In wild-type mice, there was a significant increase in MNTB volume between P1 $\left(42,502 \pm 3856 \mu \mathrm{m}^{2}\right)$ and P6 $(59,974$ $\left.\pm 3310 \mu \mathrm{m}^{2}\right)$, and between P6 and P14 (100,662 \pm 1976 $\mu \mathrm{m}^{2}$ ). MNTB size in Fmr1 KO mice also showed gains at 


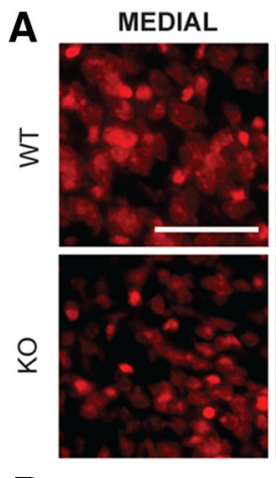

LATERAL

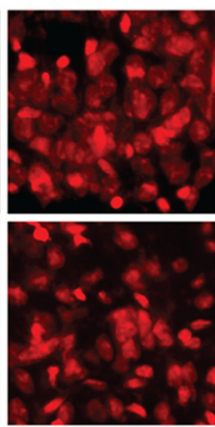

B
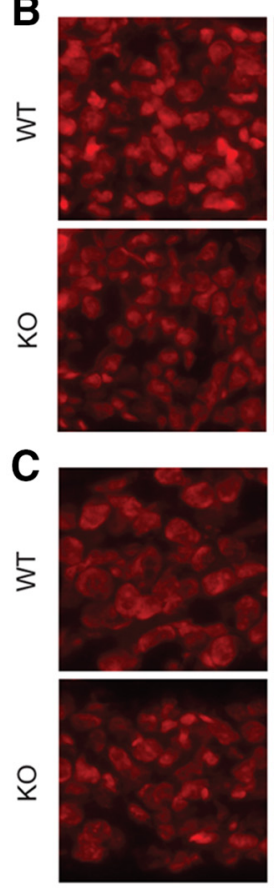
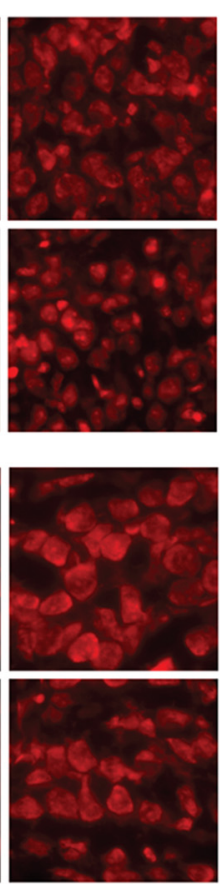

D

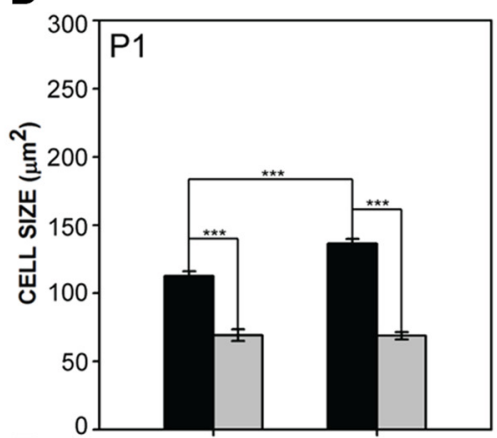

E
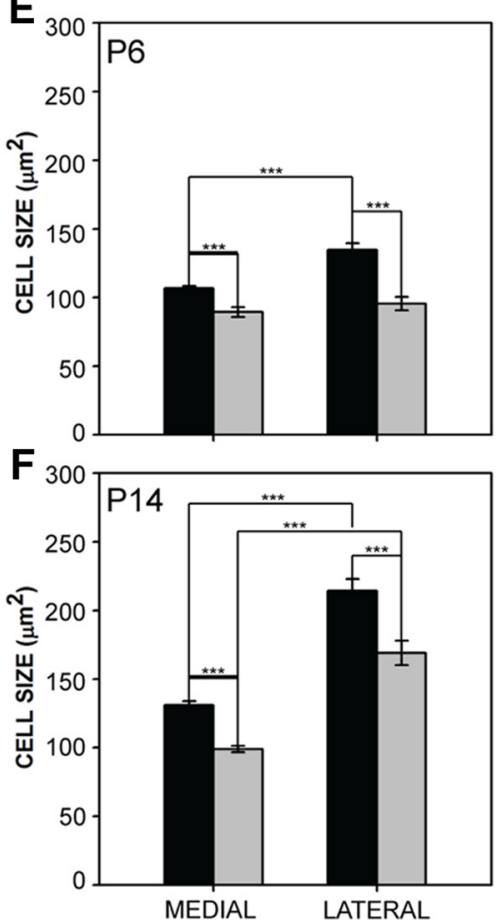

Figure 3. MNTB cell size was reduced and medial-lateral cell size gradient development delayed in Fmr1 KO mice. A-C, Cell area in wild-type and Fmr1 KO MNTB at P1, P6, and P14. D-F, Cells in the Fmr1 KO medial and lateral MNTB were smaller than those found in wild-type mice at $\mathrm{P} 1, \mathrm{P} 6$, and $\mathrm{P} 14$. In $\mathrm{P} 1$ and $\mathrm{P} 6$ wild-type mice, medial MNTB cells were significantly smaller than lateral MNTB cells, but in Fmr1 KO mice, this difference was not observed. By P14, both genotypes showed significantly smaller cell size in medial MNTB compared to lateral MNTB. Scale bar in $\boldsymbol{A}=100 \mu \mathrm{m}$; applies to $\boldsymbol{A}-\boldsymbol{C}$. $*, p<0.05 ; * *, p<0.01 ;$ and $* * *, p<0.001$.

each age tested; a significant change in MNTB size was found between P1 $\left(42,979 \pm 5051 \mu \mathrm{m}^{2}\right)$ and P6 $(57,020 \pm$ $\left.2837 \mu \mathrm{m}^{2}\right)$, and a significant increase was seen between $\mathrm{P} 6$ and P14 (93,280 $\pm 2108 \mu \mathrm{m}^{2}$; Fig. 5E). The number of cells within MNTB increased significantly with age $\left(F_{2,59}\right.$ $=28.024, p<0.001$ ), though the number of cells did not differ by genotype $\left(\mathrm{F}_{1,59}=0.009, p=0.925\right)$. In both wild-type and Fmr1 KO mice, the number of cells in MNTB increased significantly from $\mathrm{P} 1$ to $\mathrm{P} 6$, but the increase from P6 to P14 did not reach significance in wild-type mice (Fig. 5F). In wild-type mice, there were $210.5 \pm 16.5$ cells in MNTB sections at P1, 322.7 \pm 18.8 cells at P6, and $355.2 \pm 12.7$ cells at P14. Fmr $1 \mathrm{KO}$ mice had 213.8 \pm 18.2 cells in MNTB at P1, $302.8 \pm 18.1$ cells at P6, and $367.3 \pm 16.8$ cells at P14. The growth of MNTB thus does not appear to differ between mutants and wild-type mice.
LSO

Similar to VCN and MNTB findings, LSO nucleus size and number of cells did not differ between wild-type and Fmr1 KO mice. LSO mean cross-sectional area significantly increased with age in both wild-type and Fmr1 KO mice $\left(F_{2,59}=60.344, p<0.001\right)$, but did not vary by genotype $\left(F_{1,59}=0.792, p=0.377\right.$; Fig. $\left.5 G\right)$. LSO size increased significantly from $\mathrm{P} 1$ to $\mathrm{P} 6$ and from $\mathrm{P} 1$ to $\mathrm{P} 14$ in wild-type and Fmr1 KO mice, and Fmr1 KO LSO also showed an increase from P6 to P14 (Fig. $5 H$ ). At P1, the LSO was 29,692 $\pm 2257 \mu \mathrm{m}^{2}$ in wild-type mice and $38,352 \pm 2725 \mu \mathrm{m}^{2}$ in Fmr1 KO mice. At P6, the wild-type LSO was $77,281 \pm 4659 \mu \mathrm{m}^{2}$ and the $F m r 1 \mathrm{KO}$ LSO was $80,564 \pm 7872 \mu \mathrm{m}^{2}$. At P14, LSO in wild-type mice was $102,910 \pm 4226 \mu \mathrm{m}^{2}$ and 104,473 $\pm 3938 \mu \mathrm{m}^{2}$ in Fmr1 $\mathrm{KO}$ mice. The number of cells within LSO also increased with age $\left(F_{2,59}=35.620, p<0.001\right)$, but not with geno- 


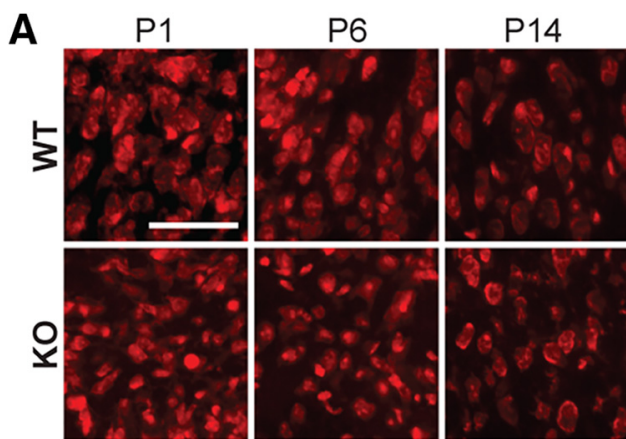

B

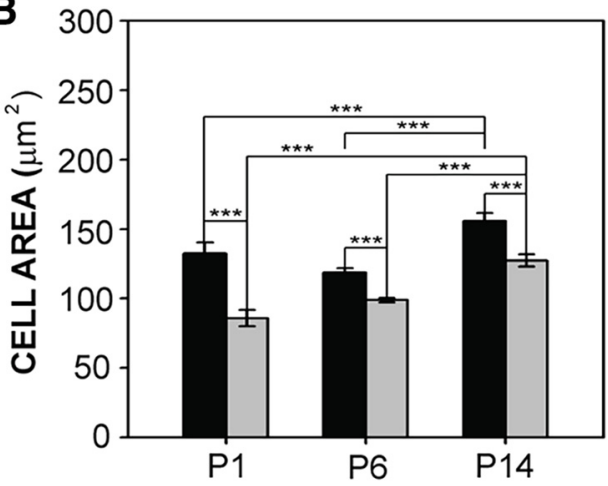

Figure 4. LSO cell size in wild-type and Fmr1 KO mice. $\boldsymbol{A}$, Fluorescent Nissl stain in LSO in wild-type mice (top) and Fmr1 $\mathrm{KO}$ mice (bottom) at P1, P6, and P14. Scale bar $=100 \mu \mathrm{m}$. B, Fmr1 KO cell size was significantly smaller than those in wildtype mice at all ages tested. *, $p<0.05$; **, $p<0.01$; and ***, $p<0.001$.

type $\left(F_{1,59}=0.724, p=0.398 ;\right.$ Fig. $\left.5 /\right)$. Both wild-type and Fmr1 KO mice showed significant increases in the number of LSO cells from P1 (WT: $144.8 \pm 10.7$; KO: $171.5 \pm 12.5)$ to P6 (WT: $319.8 \pm 15.3 ; \mathrm{KO}: 309.0 \pm 27.6)$ and from P1 to P14 (WT: $351.4 \pm 19.7$; KO: $385.9 \pm 17.1$ ). This finding is consistent with data showing no significant difference in the LSO cell density of adult Fmr1 KO mice (Rotschafer et al., 2015).

\section{Inhibitory and excitatory synaptic markers in the developing auditory brainstem}

Levels of VGLUT and VGAT, markers for excitatory and inhibitory synaptic inputs, respectively, have been shown to be altered in the auditory brainstem in adult Fmr1 KO mice (Rotschafer et al., 2015; Garcia-Pino et al., 2017). We thus examined the developmental emergence of changes in markers of synaptic input in wild-type and mutant mice.

VCN

The expression values of VGLUT and VGAT in VCN are shown in Fig. 6A, B. In addition, we examined expression of synaptophysin during development to evaluate the numbers of presynaptic inputs (Fig. 6C). In VCN, the fractional coverage of VGLUT and VGAT significantly decreased with age (VGLUT: $F_{1,43}=30.666, p<0.001$; VGAT: $\left.F_{1,43}=10.846, p=0.002\right)$, but no difference in the amount of VGLUT or VGAT was found between genotypes at any age tested (VGLUT: $F_{1,43}=0.009, p=0.926$; VGAT: $F_{1,43}=0.098, p=0.756$; Fig. $6 D, E$ ). VGLUT fractional coverage in the wild-type VCN was $0.14 \pm 0.02$ at $\mathrm{P} 6$ and $0.07 \pm 0.004$ at $\mathrm{P} 14$, whereas Fmr1 KO fractional coverage was $0.12 \pm 0.01$ at $\mathrm{P} 6$ and $0.07 \pm 0.005$ at P14. VGAT fractional coverage in wild-type mice was $0.10 \pm 0.02$ at $P 6$ and $0.08 \pm 0.01$ at P14. In Fmr1 KO mice, VGAT fractional coverage was $0.10 \pm 0.01$ at $P 6$ and $0.07 \pm 0.004$ at P14. Using synaptophysin fractional coverage, we determined that there was no significant difference in the amount of synaptic inputs to VCN between genotypes $\left(F_{1,29}=3.178, p=0.085\right)$ or ages $\left(F_{1,29}\right.$ $=1.350, p=0.255$; Fig. $6 F$ ). Wild-type synaptophysin fractional coverage at $\mathrm{P} 6$ was $0.12 \pm 0.007$ and at P14 was $0.13 \pm 0.006 ;$ Fmr1 $\mathrm{KO}$ coverage at P6 was $0.13 \pm$ 0.003 and at P14 was $0.14 \pm 0.005$. The relative levels of VGLUT and VGAT, expressed as $I_{\mathrm{SP}}$ values, were significantly different for age $\left(F_{1,43}=15.330, p<0.001\right.$; Fig. $\left.6 G\right)$ but not for genotype $\left(F_{1,43}=0.195, p=0.661\right)$. At P6, the $\mathrm{I}_{\mathrm{SP}}$ value was $0.12 \pm 0.04$ in wild-type mice and $0.04 \pm$ 0.04 in Fmr1 KO mice. At P14, the $\mathrm{I}_{\mathrm{SP}}$ value was $-0.05 \pm$ 0.04 in wild-type mice and $-0.03 \pm 0.01$ in $F m r 1 \mathrm{KO}$ mice. Thus, as in adult Fmr1 KO mice, synaptic inputs to VCN were not altered.

\section{MNTB}

We evaluated expression of presynaptic markers in MNTB (Fig. 7A-C). VGLUT fractional coverage was similar between the genotypes $\left(F_{1,22}=0.417, p=0.525\right.$; Fig. $7 D$ ), but VGAT fractional coverage was significantly greater in $F m r 1 \mathrm{KO}$ mice $\left(F_{1,22}=66.730, p<0.001\right.$; Fig.

Table 2. Correlation coefficients and statistics comparing cell size across nuclei

\begin{tabular}{lll}
\hline $\begin{array}{l}\text { Source } \\
\text { P6 wild type }\end{array}$ & MNTB cell size & LSO cell size \\
$\quad$ VCN cell size & Pearson's $r=0.014 ; p=0.975 ; n=8$ & Pearson's $r=0.393 ; p=0.335 ; n=8$ \\
$\quad$ MNTB cell size & - & Pearson's $r=-0.375 ; p=0.360 ; n=8$ \\
$\begin{array}{l}\text { P6 Fmr1 KO } \\
\text { VCN cell size }\end{array}$ & Pearson's $r=0.675 ; p=0.096 ; n=7$ & Pearson's $r=-0.544 ; p=0.068 ; n=12$ \\
$\quad$ MNTB cell size & - & Pearson's $r=-0.785 ; p=0.037 ; n=7$ \\
P14 wild type & & Pearson's $r=0.655 ; p=0.008 ; n=15$ \\
$\quad$ VCN cell size & Pearson's $r=-0.239 ; p=0.507 ; n=10$ & Pearson's $r=0.440 ; p=0.203 ; n=10$ \\
MNTB cell size & - & Pearson's $r=0.772 ; p=0.0012 ; n=14$ \\
P14 Fmr1 KO & & Pearson's $r=0.048 ; p=0.902 ; n=9$ \\
$\quad$ VCN cell size & Pearson's $r=-0.176 ; p=0.650 ; n=9$ &
\end{tabular}


VCN

A
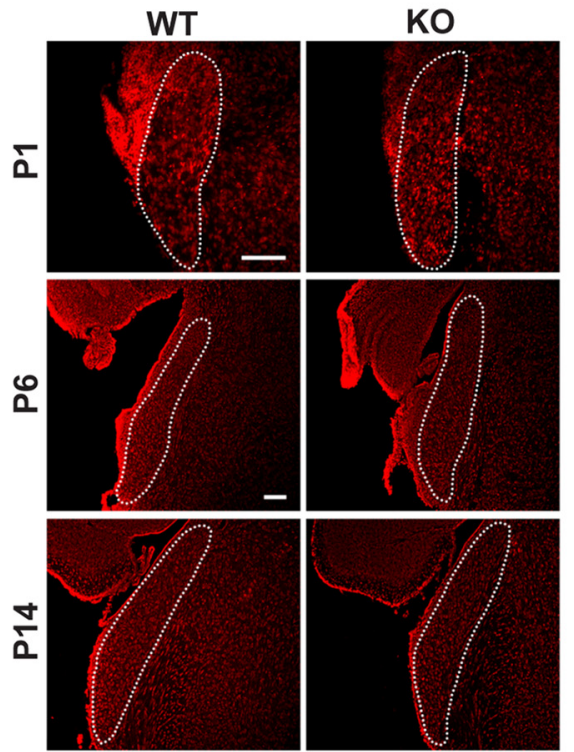

B

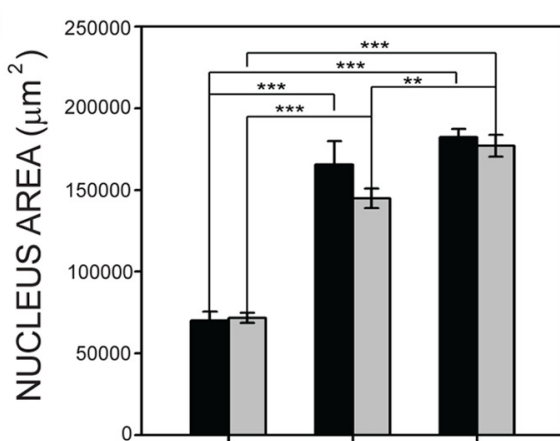

C

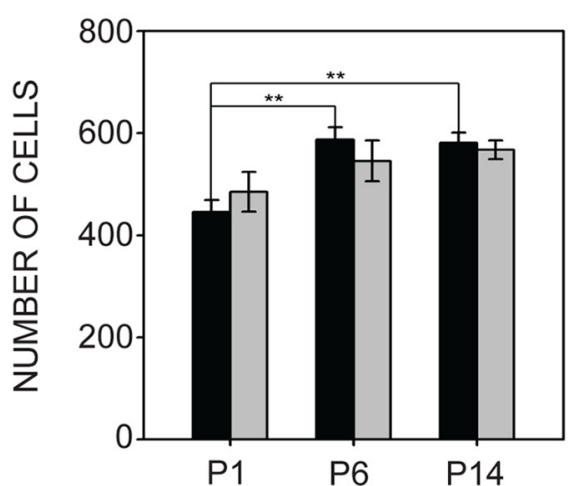

MNTB
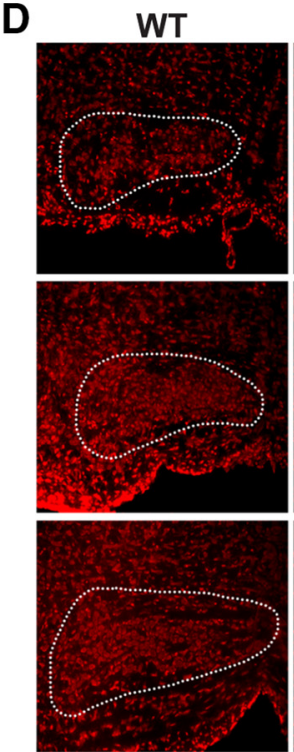

E

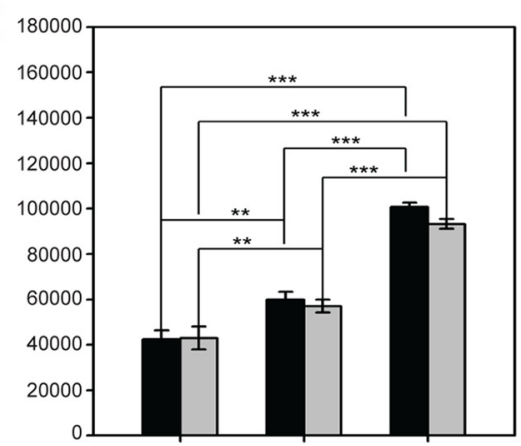

F

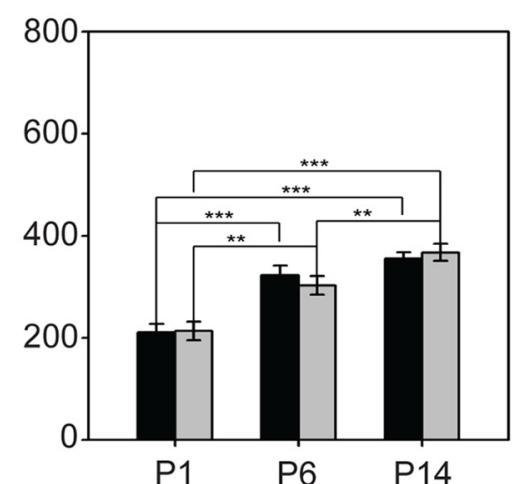

LSO

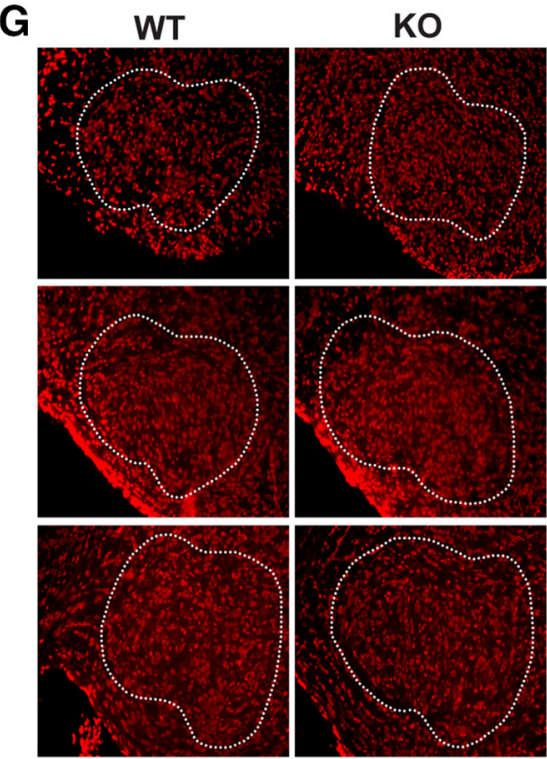

H

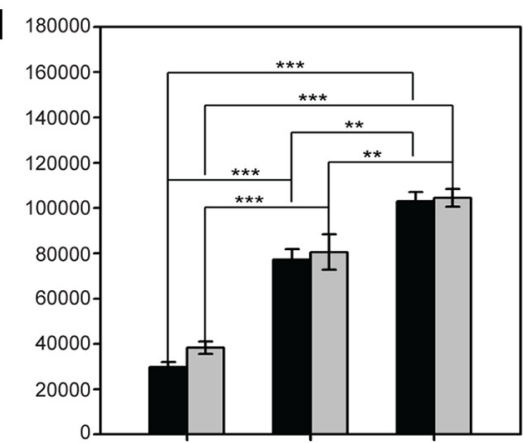

I

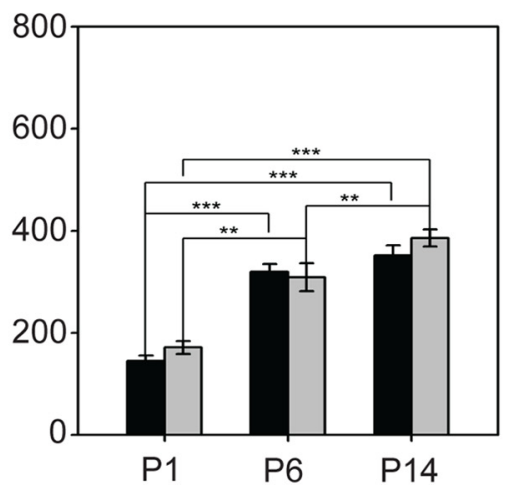

Figure 5. Nucleus growth and cell acquisition in wild-type and Fmr1 KO mice. A, Outlines of VCN in coronal sections at P1, P6, and $\mathrm{P} 14$. Medial is to the right. $\boldsymbol{B}$, In VCN, both wild-type mice and Fmr1 KO mice show age-related increases in nucleus area. $\boldsymbol{C}$, The number of cells in the wild-type VCN increased with age. Increases in cell number in Fmr1 KO mice did not reach significance. $\boldsymbol{D}$, Outlines of MNTB in wild-type and Fmr1 KO mice at P1, P6, and P14. E, In MNTB, wild-type and Fmr1 KO mice both showed significant increases in nucleus size at all ages tested. $\boldsymbol{F}$, Both wild-type mice and $F m r 1 \mathrm{KO}$ mice showed age-dependent increases in cell number in MNTB. G, Outlines of LSO in wild-type and Fmr1 KO mice at P1, P6, and P14. $\boldsymbol{H}$, LSO grew in size at each age in both wild-type and Fmr1 KO mice. I, The number of cells in LSO in both wild-type mice and Fmr1 KO mice increased significantly with age. Top row in $\boldsymbol{A}$ : $100-\mu \mathrm{m}$ scale bar applies to P1 images (20× magnification). Second row in $\boldsymbol{A}: 100-\mu \mathrm{m}$ scale bar applies to for P6 and P14 images (10× magnification). *, $p<0.05 ; * *, p<0.01$; and ***, $p<0.001$.

$7 E$ ) at both ages. Neither VGLUT nor VGAT coverage changed significantly from P6 to P14 (VGLUT: $F_{1,22}=$ 0.283, $p=0.600$; VGAT: $F_{1,22}=0.804, p=0.379$ ). At P6, wild-type VGLUT fractional coverage was $0.08 \pm 0.01$ and VGAT coverage was $0.02 \pm 0.001$. P6 Fmr1 KO fractional coverage for VGLUT was $0.07 \pm 0.003$ and for VGAT was $0.03 \pm 0.001$. At P14, VGLUT coverage in wild-type mice was $0.07 \pm 0.01$ and in Fmr1 KO mice was $0.08 \pm 0.005$; VGAT coverage in wild-type mice was $0.02 \pm 0.002$ and in Fmr1 KO mice was $0.03 \pm 0.002$. Overall, synaptophysin 

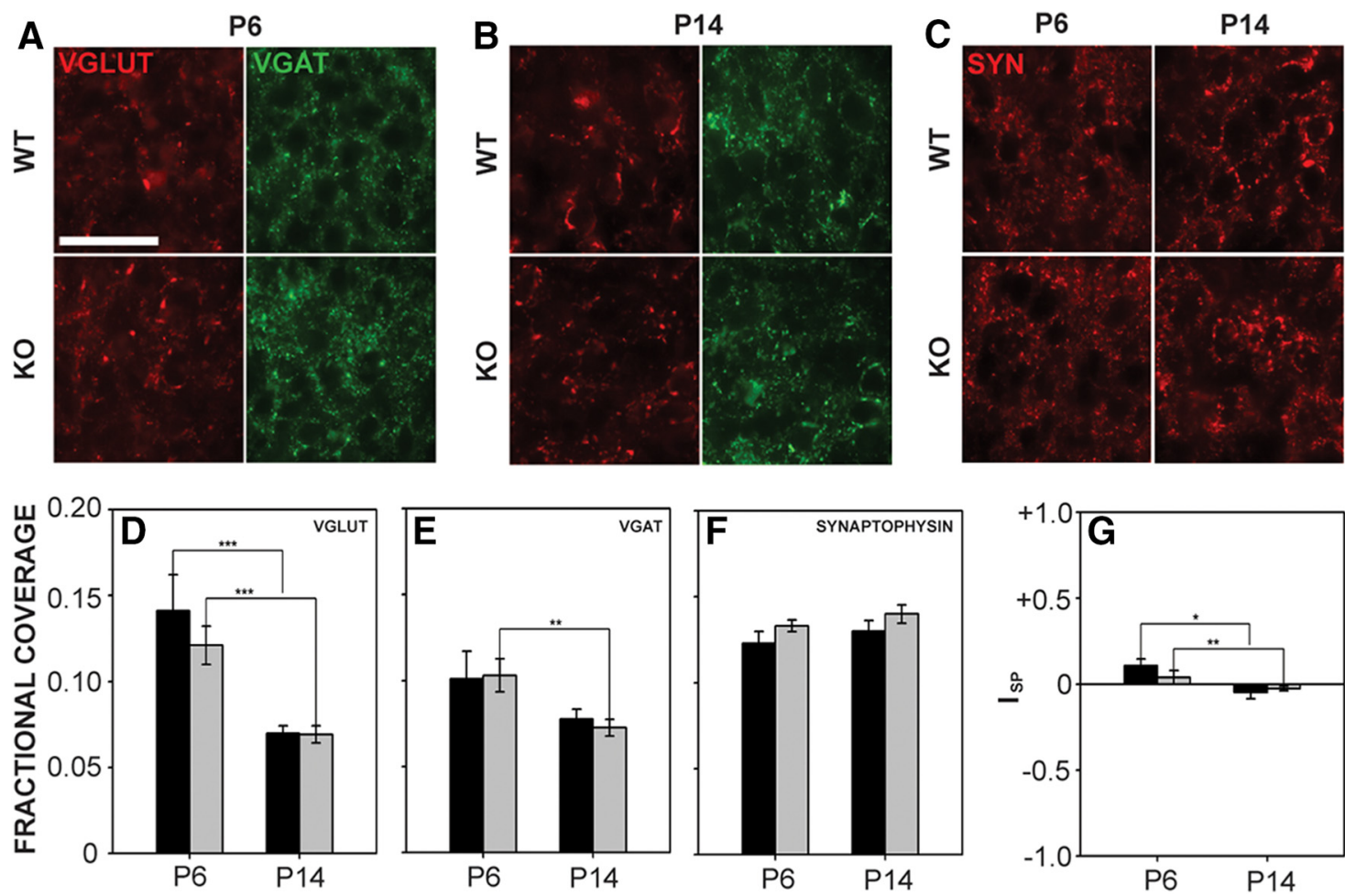

Figure 6. VGLUT, VGAT, and synaptophysin expression in VCN. $\boldsymbol{A}, \boldsymbol{B}$, VGLUT and VGAT immunofluorescence in VCN in wild-type (top) and Fmr1 KO (bottom) mice at P6 (A) and P14 (B). C, Synaptophysin expression in VCN in wild-type (top) and Fmr1 KO (bottom) mice at P6 (left) and P14 (right). $\boldsymbol{D}$, In VCN in both wild-type and Fmr1 KO mice, VGLUT fractional coverage was reduced at P14 compared to P6, but did not vary between genotypes. $\boldsymbol{E}$, VGAT fractional coverage decreased significantly from P6 to P14 in Fmr1 KO mice. $\boldsymbol{F}$, Synaptophysin fractional coverage did not differ with age or genotype. $\boldsymbol{G}$, VGLUT relative to VGAT expression (I $\mathrm{SP})$ did not differ significantly between genotypes, but $\mathrm{I}_{\mathrm{SP}}$ values decreased significantly from P6 to P14. Scale bar in $\boldsymbol{A}=50 \mu \mathrm{m}$; applies to A-C. *, $p<0.05 ; * *, p<0.01$; and ***, $p<0.001$.

fractional coverage was significantly greater in Fmr1 KO mice than in wild-type mice $\left(F_{1,25}=4.347, p=0.047\right.$; Fig. $7 C, F)$; however, post hoc analysis at each age did not reach significance $\left(F_{1,25}=1.785, p=0.194\right)$. At P6, synaptophysin coverage in wild-type mice was $0.10 \pm$ 0.01 and $0.12 \pm 0.02$ in Fmr1 KO mice. Wild type coverage at $\mathrm{P} 14$ was $0.10 \pm 0.005$, and $F m r 1 \mathrm{KO}$ coverage was $0.12 \pm 0.005$. Relative levels of VGLUT and VGAT expressed as $I_{\mathrm{SP}}$ values (Fig. 7G) were significantly smaller in Fmr1 KO mice than in wild-type mice $\left(F_{1,22}=23.979, p<\right.$ 0.001 ), indicative of reduced excitatory input relative to inhibitory input. No changes in $I_{S P}$ values were found with age $\left(F_{1,22}=1.291, p=0.268\right)$. I $\mathrm{SP}$ values in wild-type mice were $0.59 \pm 0.03$ at $\mathrm{P} 6$ and $0.60 \pm 0.06$ at P14. In Fmr1 $\mathrm{KO}$ mice, $\mathrm{I}_{\mathrm{SP}}$ values were $0.38 \pm 0.03$ at $\mathrm{P} 6$ and $0.45 \pm$ 0.03 at P14. These results suggest that greater VGAT fractional coverage values drive a decrease in Fmr1 KO $I_{S P}$ values and that this phenotype is present early in postnatal development.

\section{LSO}

VGLUT, VGAT, and synaptophysin expression were examined in LSO (Fig. 8A-C). VGLUT and fractional coverage significantly decreased with age in wild-type and Fmr1 KO mice, and VGAT coverage increased with age (VGLUT: $F_{1,43}=16.857, p<0.001$; VGAT: $F_{1,43}=13.242$, $p<0.001$ ), although there was no difference between genotypes (VGLUT: $F_{1,43}=0.210, p=0.649$; VGAT: $F_{1,43}$
$=0.991, p=0.325$; Fig. $8 D, E)$. Fractional VGLUT coverage was $0.14 \pm 0.03$ at $\mathrm{P} 6$ and $0.07 \pm 0.006$ at $\mathrm{P} 14$ in wild-type mice, and $0.12 \pm 0.02$ at $\mathrm{P} 6$ and $0.07 \pm 0.006$ at P14 in Fmr1 KO mice. VGAT fractional coverage in wild-type mice was $0.03 \pm 0.002$ at $\mathrm{P} 6$ and $0.05 \pm 0.01$ at P14. In Fmr1 KO mice, VGAT coverage was $0.03 \pm 0.004$ at $\mathrm{P} 6$ and $0.06 \pm 0.007$ at $\mathrm{P} 14$. Synaptophysin fractional coverage was significantly greater in $F m r 1 \mathrm{KO}$ mice $\left(F_{1,30}\right.$ $=40.622, p<0.001$ ) at both P6 and P14 (Fig. 8F). There was also a significant difference in synaptophysin expression between ages $\left(F_{1,30}=5.388, p=0.027\right)$. In wild-type mice, LSO $I_{S P}$ values were $0.59 \pm 0.07$ at $P 6$ and $0.21 \pm$ 0.09 at $\mathrm{P} 14$. In Fmr1 $\mathrm{KO}$ mice, $\mathrm{I}_{\mathrm{SP}}$ values were $0.53 \pm 0.04$ at $P 6$ and $0.04 \pm 0.03$ at $P 14$. I $I_{S P}$ values differed between genotypes at P14 $\left(F_{1,43}=4.302, p=0.044\right)$, and decreased with age $\left(F_{1,43}=62.677, p<0.001\right)$.

\section{Emergence of microglia and astrocytes in wild-type and Fmr1 KO mice}

To determine whether the Fmr1 deletion alters glial populations in the auditory brainstem, we next quantified the number of microglia and astrocytes using immunofluorescence for the markers Iba1 and ALDH1L1, respectively.

\section{Microglia}

We examined the expression of Iba1 in VCN at P1, P6, and P14 in VCN (Fig. 9A-C). A two-way ANOVA revealed 
A

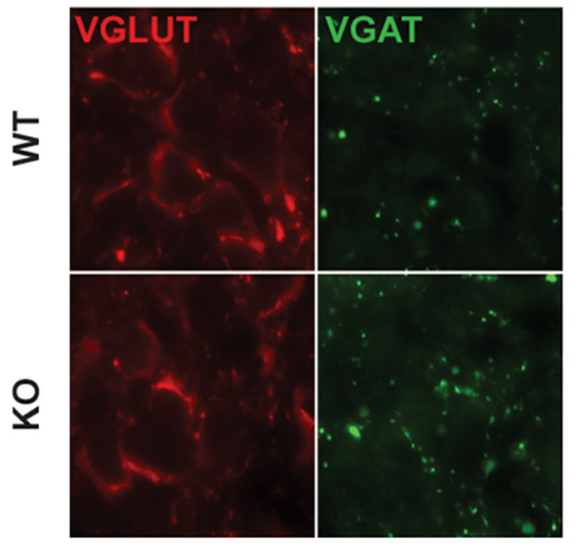

B

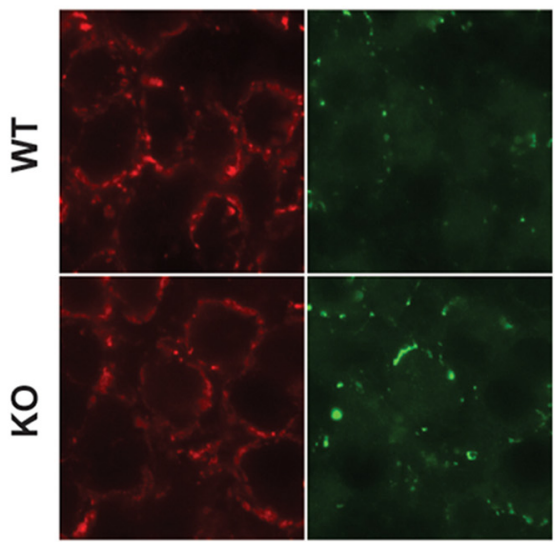

C

P6

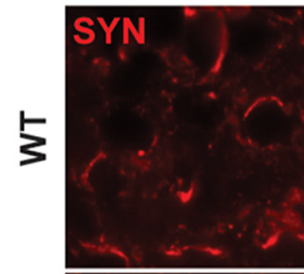

P14

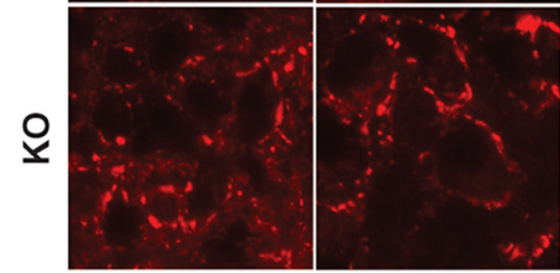

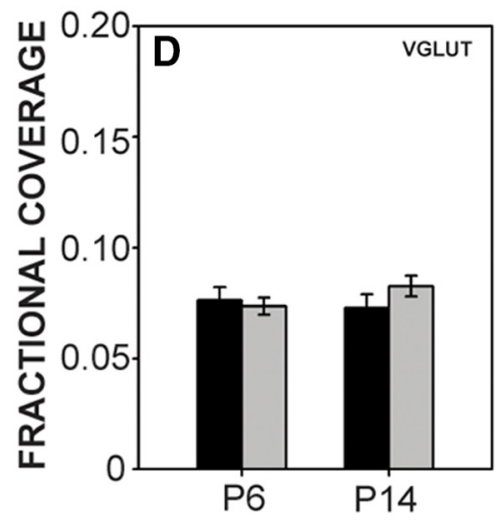
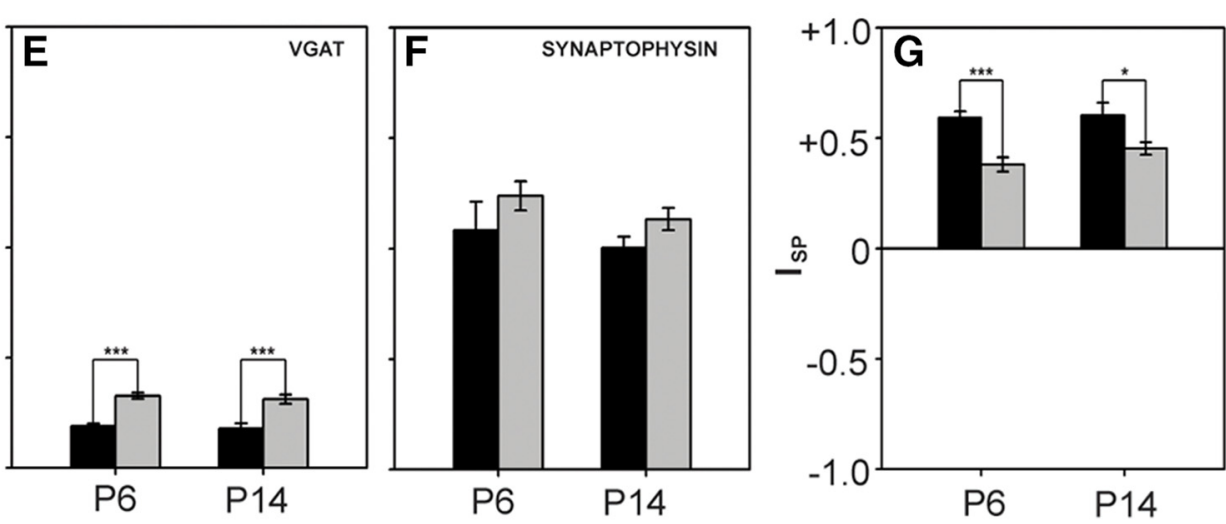

Figure 7. VGLUT, VGAT, and synaptophysin expression in MNTB. $\boldsymbol{A}, \boldsymbol{B}$, VGLUT and VGAT expression in wild-type and Fmr1 KO MNTB at P6 $(\boldsymbol{A})$ and P14 (B). C, Synaptophysin expression in MNTB in wild-type (top) and Fmr1 KO (bottom) mice. $\boldsymbol{D}$, VGLUT fractional coverage did not vary between genotypes or ages. $\boldsymbol{E}$, VGAT fractional coverage was significantly greater in Fmr1 KO MNTB at both P6 and P14. $\boldsymbol{F}$, Synaptophysin coverage did not differ significantly by age or by genotype. $\mathbf{G}$, I $\mathrm{SP}$ values were significantly smaller in Fmr1 KO mice at both P6 and P14. Scale bar in $\boldsymbol{A}=50 \mu \mathrm{m}$; applies to $\boldsymbol{A}-\boldsymbol{C}$. $*, p<0.05 ; * *, p<0.01 ;$ and $* * *, p<0.001$.

that the number of microglia varied with age $\left(F_{2,53}=\right.$ $24.955, p<0.001)$ but not with genotype $\left(F_{1,53}=0.1 .250\right.$, $p=0.269$; Fig. 9D). Wild-type VCN had an average of 0.4 \pm 0.1 microglia per VCN section at $\mathrm{P} 1,18.43 \pm 4.38$ at $\mathrm{P} 6$, and $25.13 \pm 1.94$ at $\mathrm{P} 14 ;$ Fmr1 $\mathrm{KO}$ VCN had $5.00 \pm$ 1.08 microglia per $\mathrm{VCN}$ section at $\mathrm{P} 1,19.60 \pm 2.19$ at $\mathrm{P} 6$, and $28.52 \pm 3.16$ at P14. Expression of Iba1 in MNTB (Fig. $9 E-G)$ also varied with age $\left(F_{2,59}=52.928, p<0.001\right.$; Fig. $10 E-H)$ but not with genotype $\left(F_{1,59}=0.219, p=0.642\right.$; Fig. $9 H$ ). Mean numbers of microglia in wild-type MNTB sections were $0.62 \pm 0.25$ at $\mathrm{P} 1,11.06 \pm 1.30$ at $\mathrm{P} 6$, and $16.18 \pm 1.21$ at P14. For Fmr1 KO mice, mean numbers of microglia were $2.08 \pm 0.39$ at $\mathrm{P} 1,6.86 \pm 0.78$ at $\mathrm{P} 6$, and $16.91 \pm 1.71$ at $\mathrm{P} 14$. Similarly, Iba1 expression in LSO (Fig. 9/-K) increased with age $\left(F_{2,59}=50.641, p<0.001\right)$, but did not depend on genotype $\left(F_{1,59}=0.783, p=0.380\right.$; Fig. 9L). In wild-type LSO, there was a consistent increase in the number of microglia from P1 (1.37 \pm 0.24$)$ to P6 (11.16 \pm 2.14), and to P14 (20.88 \pm 1.02). In Fmr1 KO mice, there was a significant difference in the number of microglia in LSO between P1 (1.55 \pm 0.29$)$ and P6 (9.53 \pm 1.34), between P6 and P14 (18.94 \pm 2.01$)$. Thus, no difference between wild-type mice and Fmr1 KO mice was seen in microglial numbers in these auditory brains- tem nuclei. We examined Pearson's correlation coefficients to determine correlation of the number of microglia with values for VGAT, VGLUT, and synaptophysin in mutants and wild-type animals at P6 and P14 in each nucleus and used Bonferroni correction for these multiple comparisons. A significant positive correlation was found only between Iba1 values and VGLUT values for P6 in MNTB in Fmr1 KO mice (Table 3).

\section{Astrocytes}

We next examined the emergence of ALDH1L1-positive astrocytes in the auditory brainstem nuclei at P6 and P14. In VCN (Fig. 10A), there was a significant increase in the number of astrocytes with age $\left(F_{1,35}=21.766, p<0.001\right.$; Fig. 10A, B), and in addition, there was a significant difference in the number of astrocytes by genotype at P14 $\left(F_{1,35}=5.393, p=0.026\right.$; Fig. $\left.10 B\right)$. Wild-type mice had $5.35 \pm 1.10$ astrocytes per VCN section at P6 and 16.16 \pm 3.28 at $\mathrm{P} 14$. Fmr1 KO mice had $8.63 \pm 1.24$ at $\mathrm{P} 6$ and $27.79 \pm 4.45$ at $\mathrm{P} 14$.

In MNTB, we found that ALDH1L1-positive astrocytes increased with age $\left(F_{1,38}=19.654, p<0.001\right)$ but did not differ between genotypes $\left(F_{1,38}=1.462, p=0.234\right.$; Fig. $10 C, D)$. In wild-type mice, the mean number of astrocytes 
A

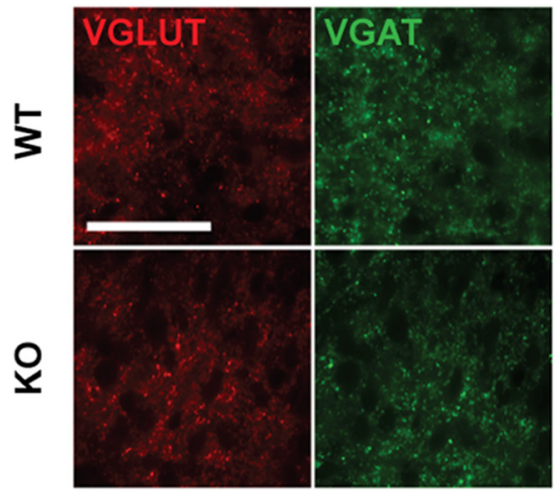

B

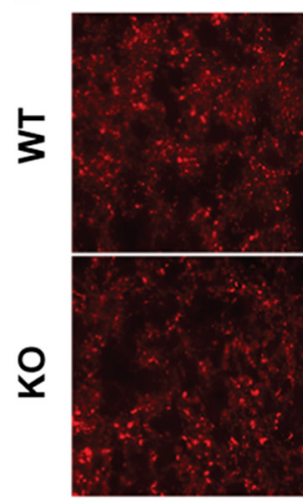

P14

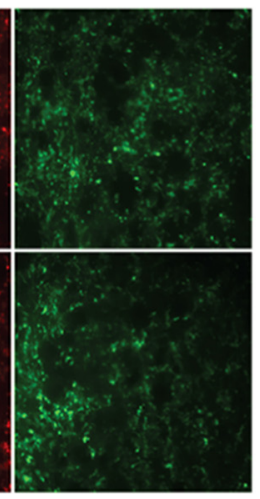

C
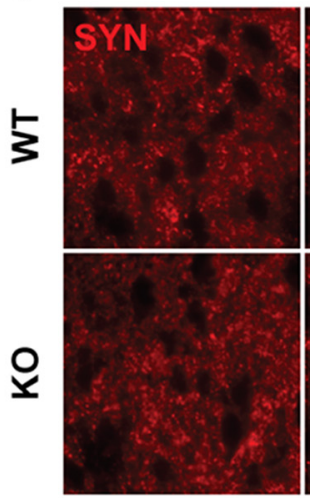

P14

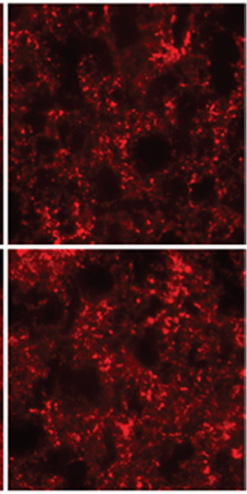

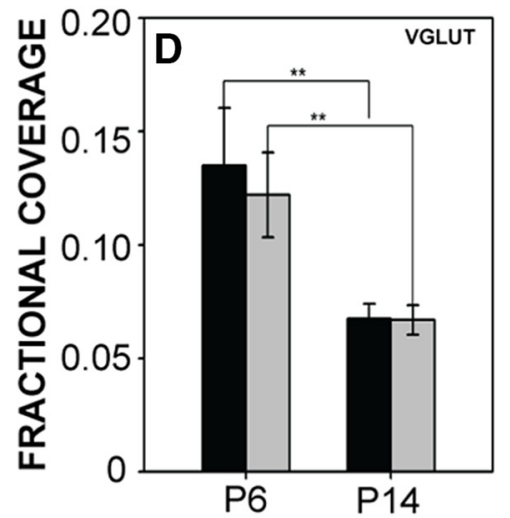
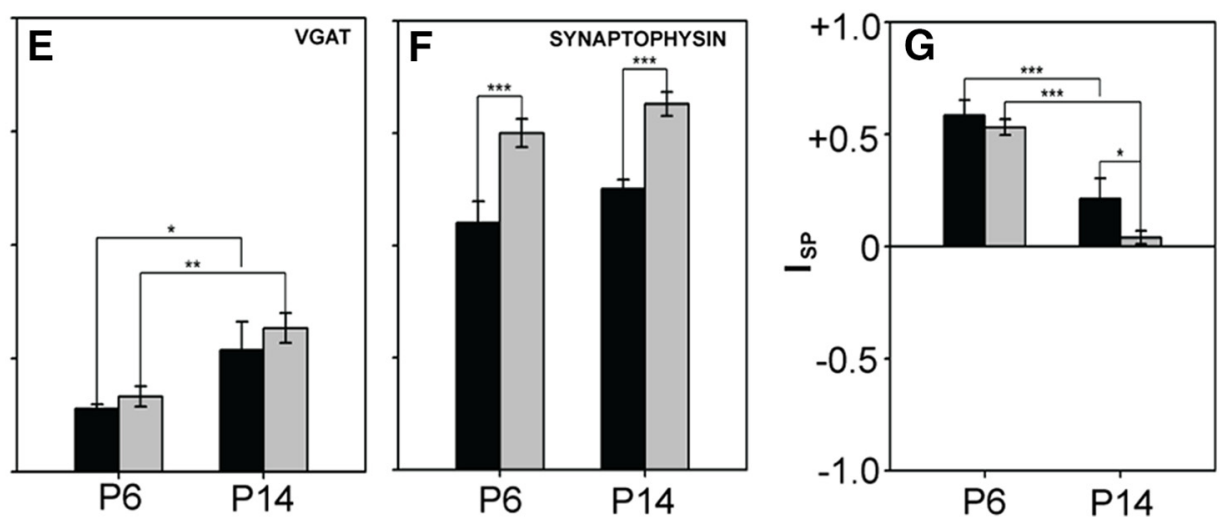

Figure 8. VGLUT, VGAT, and synaptophysin expression in LSO. A, B, Expression of VGLUT (left) and VGAT (right) at P6 and P14 in LSO. C, Synaptophysin expression at P6 and P14 in wild-type and mutant mice. D, In both wild-type and Fmr1 KO LSO, VGLUT expression decreased with age but did not differ between genotypes. $\boldsymbol{E}$, VGAT fractional coverage increased between P6 and P14 in both genotypes but did not differ between genotypes. $\boldsymbol{F}$, Synaptophysin fractional coverage was significantly greater in Fmr1 KO mice at both ages tested and did not change significantly between these ages. $G$, I $I_{\mathrm{SP}}$ values decreased significantly between P6 and P14. I $\mathrm{SP}_{\mathrm{P}}$ was significantly smaller in Fmr1 KO mice than in wild-type mice at P14. Scale bar in $\boldsymbol{A}=50 \mu \mathrm{m}$; applies to $\boldsymbol{A}-\boldsymbol{C}$. $*, p<0.05$; $* *, p<0.01$; and $* * *, p<0.001$.

per section was $3.78 \pm 0.66$ at $\mathrm{P} 6$ and $16.11 \pm 2.70$ at P14. In Fmr1 KO mice, the mean number of astrocytes per section was $5.99 \pm 1.15$ at $\mathrm{P} 6$, and $21.49 \pm 4.80$ at $\mathrm{P} 14$.

The number of astrocytes present in the LSO was significantly different between the two ages $\left(F_{1,38}=\right.$ 27.231, $p<0.001)$ and also differed between genotypes at P14 $\left(F_{1,38}=5.368, p=0.026\right)$. Wild-type and $F m r 1 \mathrm{KO}$ mice gained a significant number of astrocytes between $\mathrm{P} 6$ and $\mathrm{P} 14$, with significantly more astrocytes present in $\mathrm{P} 14 \mathrm{Fmr} 1 \mathrm{KO}$ mice than in wild-type mice. Wild-type mice had $3.95 \pm 1.12$ astrocytes per section at $P 6$ and $17.17 \pm$ 2.58 at P14; Fmr1 KO mice had $6.65 \pm 0.91$ astrocytes per section at P6 and $31.26 \pm 5.96$ at P14 (Fig. 10E, F). These results show that $F m r 1 \mathrm{KO}$ mice have significantly more astrocytes in LSO, and that these differences are evident at P14. We did not find any significant correlations between the number of astrocytes and the level of synaptophysin expression in any of the nuclei (Table 4). However, we found a strong positive correlation between ALDH1L1 levels and both VGLUT and VGAT in the P14 LSO in Fmr1 KO mice. This observation is consistent with astrocyte regulation of synaptic inputs in the mutant LSO (Table 4).

\section{Auditory brainstem phenotypes in Fmr1 KO mice are not sexually dimorphic}

To test for sex differences, we compared our outcome measures by sex in P14 mice. We used two-way ANOVAs to examine whether sex (male or female) within each genotype (wild-type or Fmr1 KO) caused significant differences in nucleus size, number of cells, cell size, synaptic proteins, or glia number in VCN, MNTB, and LSO. Although any genotype differences found were consistent with previous results, we did not find any significant differences between male and female mice in any measure tested in any nucleus examined (Table 5). We therefore conclude that FMRP loss does not selectively affect cellular or synaptic development in male or female Fmr1 KO mice within auditory brainstem nuclei.

\section{Discussion}

Previous studies of the adult Fmr1 KO mouse brainstem reported both anatomic and functional phenotypes (Rotschafer et al., 2015; Wang et al., 2015; Garcia-Pino et al., 2017). ABR measurements showed that Fmr1 KO mice had heightened ABR thresholds and reduced peak I, consistent with a modest hearing loss. Central auditory brainstem dysfunction in Fmr1 KO may thus arise secondarily from reduced peripheral input. However, FMRP is 

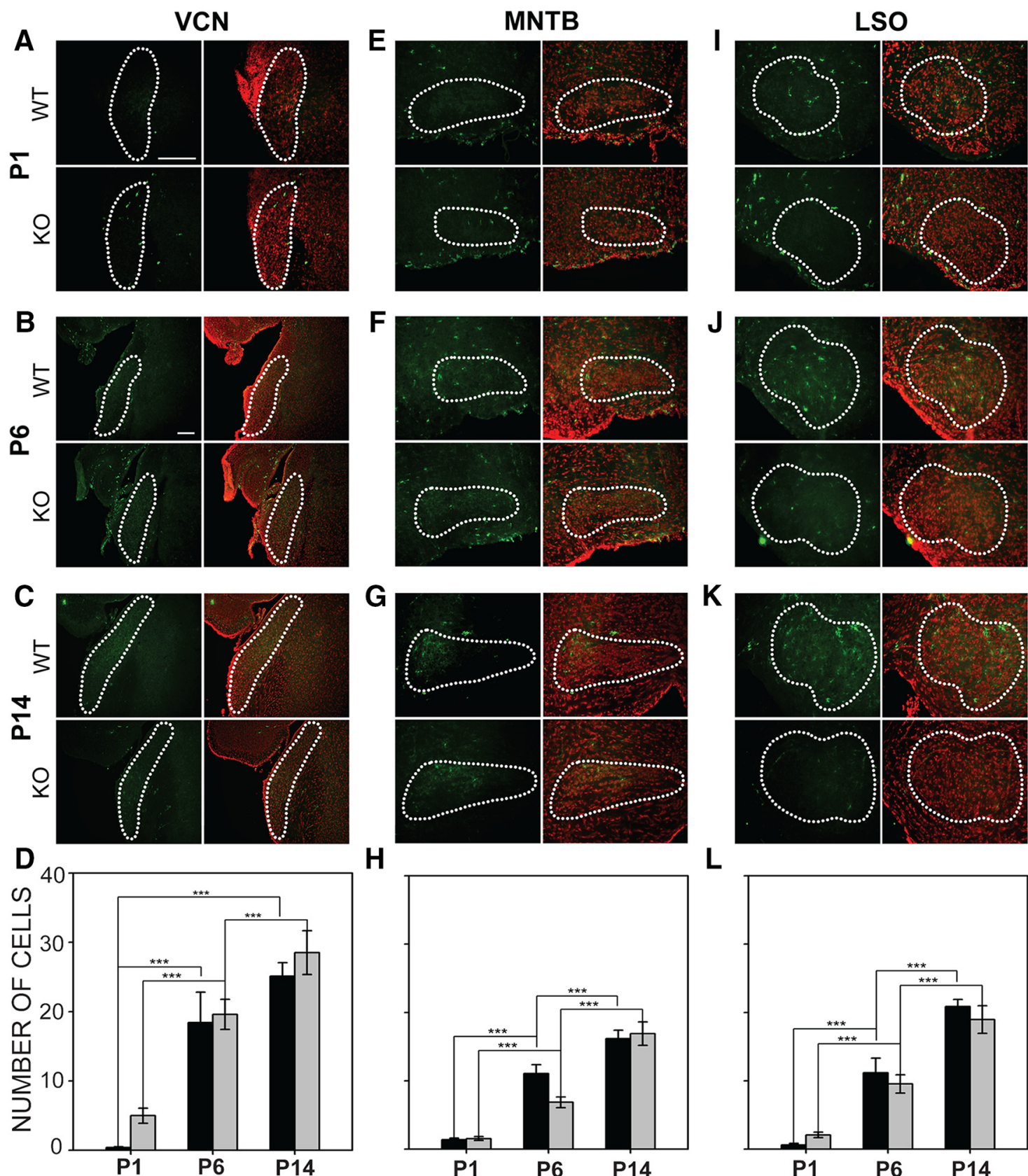

H

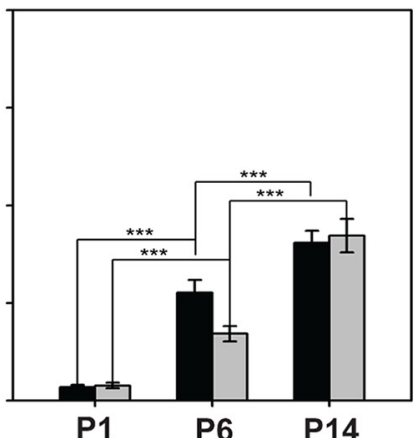

$\mathbf{L}$

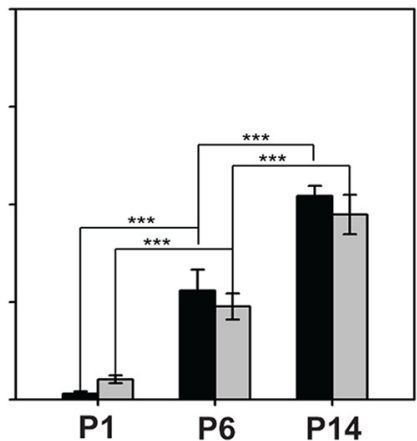

Figure 9. Emergence of microglia in the auditory brainstem nuclei in wild-type and Fmr1 KO mice. A-C, Increase in microglial population was studied in the VCN at P1, P6, and P14. Left column, Iba1 immunofluorescence in green; right column, Iba1 together with fluorescent Nissl. Nucleus outline is shown in dashed lines. $\boldsymbol{D}$, The number of microglia in VCN increased with age in both wild-type and $F m r 1 \mathrm{KO}$ mice, but no difference was seen between the genotypes. $\boldsymbol{E}-\boldsymbol{G}$, Emergence of microglia was evaluated in MNTB using Iba1 immunofluorescence (left) together with Nissl (right). $\boldsymbol{H}$, Wild type and Fmr1 KO mice both showed significant increases in the number of microglia present in MNTB each age tested, but no significant differences were found between genotypes. $\boldsymbol{I} \boldsymbol{K}$, Emergence of microglia in LSO during development. $\boldsymbol{L}$, The number of microglia expressed steadily increased at each age tested in both wild-type and Fmr1 KO mice. As for VCN and MNTB, no difference in numbers of microglia were seen between the genotypes. Scale bar in $\boldsymbol{A}=100 \mu \mathrm{m}$, applies to $\boldsymbol{A}$, $\boldsymbol{E}$, and $\boldsymbol{I}$. Scale bar in $\boldsymbol{B}=100 \mu \mathrm{m}$, applies to $\boldsymbol{B}, \boldsymbol{C}, \boldsymbol{F}, \mathbf{G}$, and $\boldsymbol{J}-\boldsymbol{K}$. $*, p<0.05 ; * *, p<0.01$; and $* * *, p<0.001$.

expressed throughout the auditory brainstem (Beebe et al., 2014; Wang et al., 2014; Ruby et al., 2015), and thus loss of FMRP may have additional effects directly on these nuclei. Here, we examined auditory brainstem development both before and after hearing onset (Hoffpauir et al., 2006; Holcomb et al., 2013) to determine to when these phenotypes emerge.

\section{Smaller neurons in auditory nuclei of Fmr1 KO mice during postnatal development}

We found broad variability among nuclei in the emergence of differences in cell size. Differences in VCN cell size were not present at any of the ages examined, and thus develop after P14. As in adults, MNTB neurons in Fmr1 KO mice were smaller than in wild type at early 

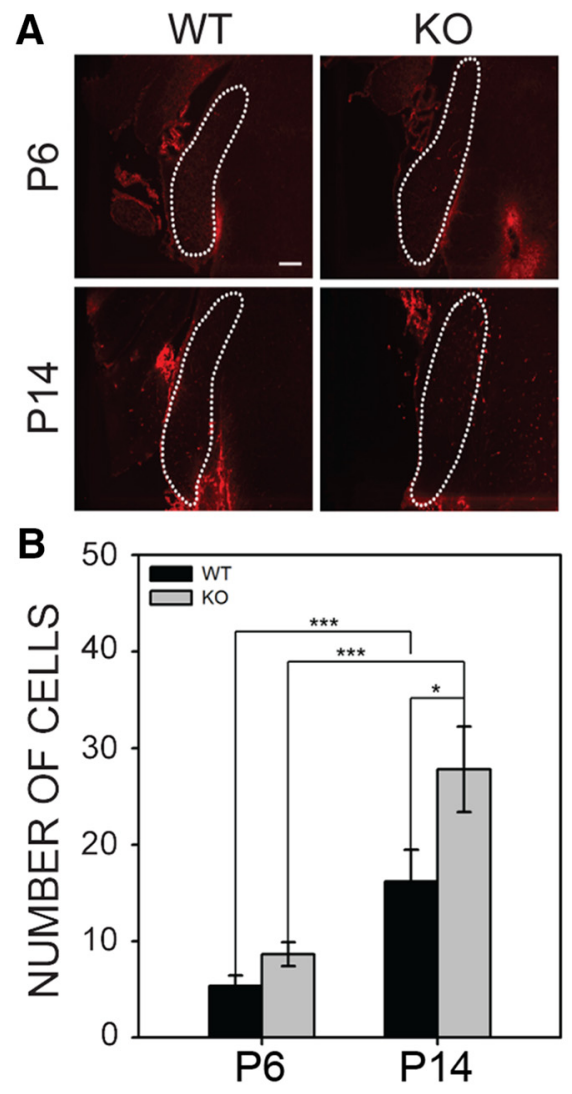
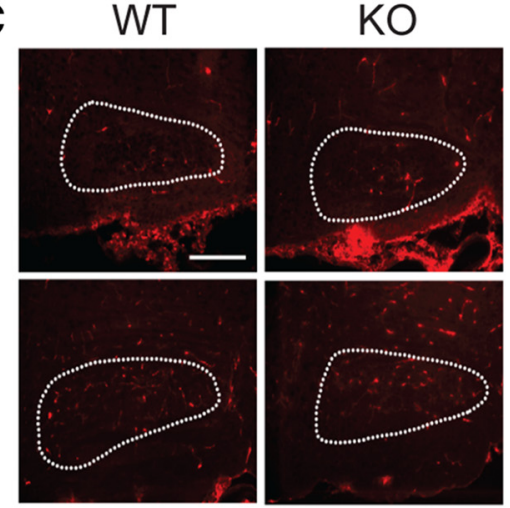

D 50

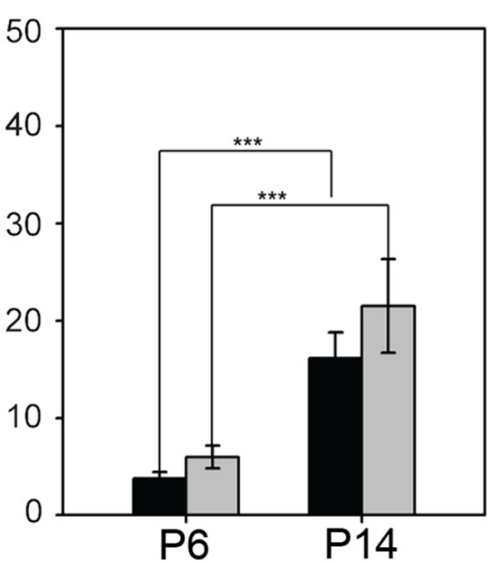

E
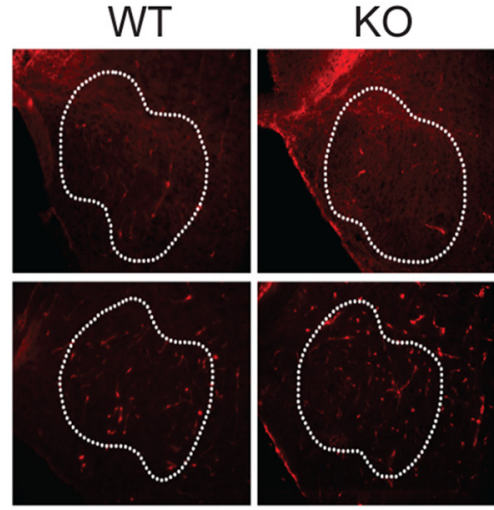

$\mathbf{F}$

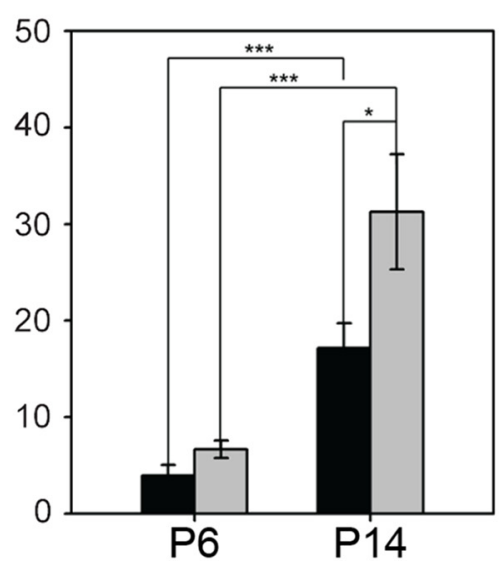

Figure 10. Emergence of astrocytes in the wild-type and Fmr1 $\mathrm{KO}$ auditory brainstem. $\boldsymbol{A}$, The number of astrocytes in the VCN was evaluated at P6 and P14 using ALDH1L1 immunofluorescence. $\boldsymbol{B}$, Numbers of ALDH1L1-positive astrocytes in VCN increased between P6 and P14 in both genotypes. At P14, there were significantly more astrocytes in VCN in Fmr1 KO mice than in wild-type mice. $\boldsymbol{C}$, Astrocytes labeled in MNTB at P6 and P14. D, Astrocyte numbers increased significantly in MNTB in both wild-type and Fmr1 KO mice, but no difference were seen between the genotypes. $\boldsymbol{E}$, ALDH1L1 immunolabeled astrocytes in LSO. $\boldsymbol{F}$, Astrocytes increased in number between P6 and P14 in both genotypes, and significantly more astrocytes were present in the Fmr1 KO LSO at P14. Scale bar in $\boldsymbol{A}=100 \mu \mathrm{m}$; scale bar in $\boldsymbol{C}=100 \mu \mathrm{m}$, applies to $\boldsymbol{C}$ and $\boldsymbol{E}$. $*, p<0.05 ; * *, p<0.01 ;$ and $* * *, p<0.001$.

postnatal ages. In contrast to VCN, these differences were already seen at $\mathrm{P} 1$, before hearing onset and before the onset of spontaneous activity (Wang and Bergles, 2015; Sierksma et al., 2017). FMRP might thus have a cell-autonomous function that regulates cell size independent of levels of synaptic input.

Our data show that a medial-lateral gradient in crosssectional cell area was evident to a moderate degree at early ages in wild-type mice and became more pronounced at P14. In contrast, the cell size gradient did not form in Fmr1 KO mice until after hearing onset. The delay in the formation of a cell size gradient in MNTB suggests a role for FMRP. FMRP is an activity-dependent negative inhibitor of mRNAs that is expressed in a medial-to-lateral gradient within MNTB (Ruby et al., 2015) and plays an important role in maintaining protein expression gradients in MNTB (Bassell and Warren, 2008; Strumbos et al., 2010). FMRP regulates expression of the potassium channel kv3.1b, which is expressed in a parallel gradient, and loss of Fmr1 results in a loss of this kv3.1b gradient (Strumbos et al., 2010). It is thus feasible that the gradient of FMRP expression, through a variety of downstream targets, contributes to the formation of the gradient of cell size. However, the eventual emergence of a size gradient in mutants suggests that FMRP is not needed for the maintenance of this gradient. A previous study demonstrated that auditory evoked activity is needed to maintain this gradient (Weatherstone et al., 2017). Taken together with our current findings, these results suggest distinct mechanisms for the establishment versus the maintenance of gradients in MNTB cell size.

In LSO, we found significant reductions in cell size in Fmr1 KO mice at all ages examined. Because these differences are not observed in adults (Rotschafer et al., 2015), our results suggest that they resolve by the time mice reach adulthood. In Fmr1 KO mice, synaptic strengthening events are delayed, but are considerably larger than those in wild-type mice (Garcia-Pino et al., 2017), and the adult Fmr1 KO LSO receives an exaggerated amount of input (Rotschafer et al., 2015; Garcia-Pino et al., 2017). Working in concert, these factors may overcome the early phenotype of smaller cells in Fmr1 KO mice.

The reduction in cell size that we observed in the early postnatal MNTB and LSO were not accompanied by any differences in the nucleus size or cell number. These observations suggest that the nuclei contain greater intercellular space. The increased number of astrocytes in 
Table 3. Correlations between lba1 expression levels and expression of each synaptic protein

\begin{tabular}{|c|c|c|}
\hline $\begin{array}{l}\text { Comparison, age, and genotype } \\
\text { Iba1 vs. VGLUT }\end{array}$ & Nucleus & Correlation coefficient and statistics \\
\hline \multicolumn{3}{|l|}{ P6 } \\
\hline Wild type & VCN & Pearson's $r=0.781 ; p=0.038 ; n=7$ \\
\hline Wild type & MNTB & Pearson's $r=0.818 ; p=0.013 ; n=8$ \\
\hline Wild type & LSO & Pearson's $r=0.664 ; p=0.073 ; n=8$ \\
\hline Fmr1 KO & VCN & Pearson's $r=0.386 ; p=0.271 ; n=10$ \\
\hline Fmr1 KO & MNTB & Pearson's $r=0.793 ; p=0.001 ; n=13$ \\
\hline Fmr1 KO & LSO & Pearson's $r=0.305 ; p=0.310 ; n=13$ \\
\hline \multicolumn{3}{|r|}{ 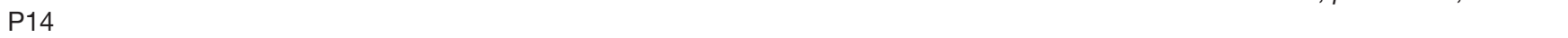 } \\
\hline Wild type & VCN & Pearson's $r=-0.179 ; p=0.620 ; n=10$ \\
\hline Wild type & MNTB & Pearson's $r=0.493 ; p=0.148 ; n=10$ \\
\hline Wild type & LSO & Pearson's $r=-0.036 ; p=0.921 ; n=10$ \\
\hline Fmr1 KO & VCN & Pearson's $r=0.176 ; p=0.515 ; n=16$ \\
\hline Fmr1 KO & MNTB & Pearson's $r=-0.039 ; p=0.887 ; n=16$ \\
\hline \multirow{2}{*}{\multicolumn{3}{|c|}{ Iba1 vs. VGAT }} \\
\hline & & \\
\hline \multicolumn{3}{|l|}{ P6 } \\
\hline Wild type & VCN & Pearson's $r=0.119 ; p=0.799 ; n=7$ \\
\hline Wild type & MNTB & Pearson's $r=0.737 ; p=0.037 ; n=8$ \\
\hline Wild type & LSO & Pearson's $r=0.236 ; p=0.574 ; n=8$ \\
\hline Fmr1 KO & VCN & Pearson's $r=0.0006 ; p=0.999 ; n=10$ \\
\hline Fmr1 KO & MNTB & Pearson's $r=0.695 ; p=0.008 ; n=13$ \\
\hline Fmr1 KO & LSO & Pearson's $r=0.130 ; p=0.673 ; n=13$ \\
\hline \multicolumn{3}{|r|}{ 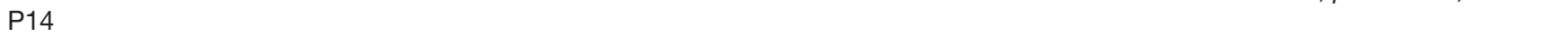 } \\
\hline Wild type & VCN & Pearson's $r=0.097 ; p=0.789 ; n=10$ \\
\hline Wild type & MNTB & Pearson's $r=0.149 ; p=0.682 ; n=10$ \\
\hline Wild type & LSO & Pearson's $r=-0.292 ; p=0.412 ; n=10$ \\
\hline Fmr1 KO & VCN & Pearson's $r=0.165 ; p=0.541 ; n=16$ \\
\hline Fmr1 KO & MNTB & Pearson's $r=-0.345 ; p=0.190 ; n=16$ \\
\hline Fmr1 KO & LSO & Pearson's $r=-0.401 ; p=0.124 ; n=16$ \\
\hline \multicolumn{3}{|l|}{ Iba1 vs. Synaptophysin } \\
\hline \multicolumn{3}{|l|}{ P6 } \\
\hline Wild type & VCN & Pearson's $r=0.422 ; p=0.346 ; n=7$ \\
\hline Wild type & MNTB & Pearson's $r=0.006 ; p=0.989 ; n=7$ \\
\hline Wild type & LSO & Pearson's $r=0.605 ; p=0.150 ; n=7$ \\
\hline Fmr1 KO & VCN & Pearson's $r=0.281 ; p=0.500 ; n=8$ \\
\hline Fmr1 KO & MNTB & Pearson's $r=0.231 ; p=0.582 ; n=8$ \\
\hline Fmr1 KO & LSO & Pearson's $r=0.203 ; p=0.629 ; n=8$ \\
\hline \multicolumn{3}{|r|}{ 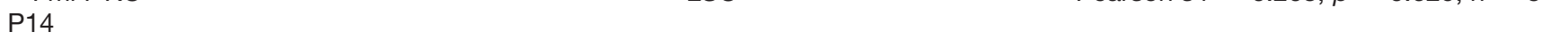 } \\
\hline Wild type & VCN & Pearson's $r=-0.115 ; p=0.751 ; n=10$ \\
\hline Wild type & MNTB & Pearson's $r=0.346 ; p=0.328 ; n=10$ \\
\hline Wild type & LSO & Pearson's $r=0.151 ; p=0.676 ; n=10$ \\
\hline Fmr1 KO & VCN & Pearson's $r=0.565 ; p=0.113 ; n=9$ \\
\hline Fmr1 KO & MNTB & Pearson's $r=-0.057 ; p=0.884 ; n=9$ \\
\hline Fmr1 KO & LSO & Pearson's $r=-0.729 ; p=0.026 ; n=9$ \\
\hline
\end{tabular}

LSO might fill some of the space. In MNTB, where this issue persists through adulthood, this space might be filled with expanded axon tracts in the ventral acoustic stria, changes in the extracellular matrix, and/or increased neuropil volume.

\section{Synaptic protein expression is altered in MNTB in Fmr1 KO mice}

Changes in neuronal excitability contribute to neurologic dysfunction in FXS (Contractor et al., 2015). In the auditory brainstem, where synaptic balance is a key factor in sound processing and sound localization (Tollin, 2003), increased excitability could lead to hyperacusis and difficulties in sound localization. Indeed, Fmr1 KO mice have shifted sensitivity for interaural level differences (Garcia-
Pino et al., 2017). Enhanced gain leading to hyperacusis in FXS may originate, at least in part, in the auditory brainstem nuclei. The increase in VGAT in MNTB, a signinverting relay nucleus, could lead to enhanced excitation in targets of MNTB (Rotschafer et al., 2015); additionally, increased excitation in LSO has also been shown to arise from VCN (Garcia-Pino et al., 2017). Both of these observations suggest that the superior olivary complex may increase gain in the auditory pathway in Fmr1 KO mice.

In MNTB, increased VGAT expression in Fmr1 KO mice was seen at P6 and persisted into adulthood. The $I_{S P}$ ratios in MNTB are generally large and positive, reflecting the presence of the large, excitatory input from the calyx of Held. Ratios are reduced in magnitude but remain positive in Fmr1 KO mice relative to wild-type mice. At 
Table 4. Correlations between ALDH1L1 expression and synaptic protein expression

\begin{tabular}{|c|c|c|}
\hline $\begin{array}{l}\text { Comparison, age, and genotype } \\
\text { ALDH1L1 vs. VGLUT }\end{array}$ & Nucleus & Correlation coefficient and statistics \\
\hline \multicolumn{3}{|l|}{ P6 } \\
\hline Wild type & VCN & Pearson's $r=0.056 ; p=0.906 ; n=7$ \\
\hline Wild type & MNTB & Pearson's $r=0.476 ; p=0.281 ; n=7$ \\
\hline Wild type & LSO & Pearson's $r=0.141 ; p=0.763 ; n=7$ \\
\hline Fmr1 KO & VCN & Pearson's $r=0.248 ; p=0.489 ; n=10$ \\
\hline Fmr1 KO & MNTB & Pearson's $r=0.207 ; p=0.566 ; n=10$ \\
\hline Fmr1 KO & LSO & Pearson's $r=0.330 ; p=0.351 ; n=10$ \\
\hline \multicolumn{3}{|r|}{ 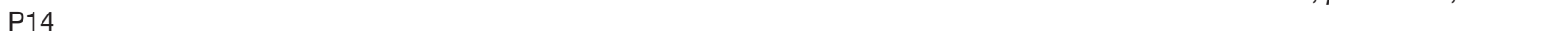 } \\
\hline Wild type & VCN & Pearson's $r=0.450 ; p=0.225 ; n=9$ \\
\hline Wild type & MNTB & Pearson's $r=0.263 ; p=0.462 ; n=10$ \\
\hline Wild type & LSO & Pearson's $r=-0.238 ; p=0.508 ; n=10$ \\
\hline Fmr1 KO & VCN & Pearson's $r=-0.507 ; p=0.135 ; n=10$ \\
\hline Fmr1 KO & MNTB & Pearson's $r=-0.675 ; p=0.023 ; n=11$ \\
\hline Fmr1 KO & LSO & Pearson's $r=0.912 ; p=0.00009 ; n=1$ \\
\hline \multicolumn{3}{|l|}{ ALDH1L1 vs. VGAT } \\
\hline \multicolumn{3}{|l|}{ P6 } \\
\hline Wild type & VCN & Pearson's $r=-0.775 ; p=0.041 ; n=7$ \\
\hline Wild type & MNTB & Pearson's $r=0.274 ; p=0.553 ; n=7$ \\
\hline Wild type & LSO & Pearson's $r=0.057 ; p=0.903 ; n=7$ \\
\hline Fmr1 KO & VCN & Pearson's $r=0.028 ; p=0.939 ; n=10$ \\
\hline Fmr1 KO & MNTB & Pearson's $r=0.449 ; p=0.193 ; n=10$ \\
\hline Fmr1 KO & LSO & Pearson's $r=-0.211 ; p=0.559 ; n=10$ \\
\hline \multicolumn{3}{|r|}{ 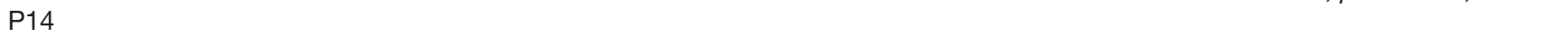 } \\
\hline Wild type & VCN & Pearson's $r=0.407 ; p=0.277 ; n=9$ \\
\hline Wild type & MNTB & Pearson's $r=0.099 ; p=0.785 ; n=10$ \\
\hline Wild type & LSO & Pearson's $r=-0.436 ; p=0.208 ; n=10$ \\
\hline Fmr1 KO & VCN & Pearson's $r=-0.721 ; p=0.019 ; n=10$ \\
\hline Fmr1 KO & MNTB & Pearson's $r=0.747 ; p=0.008 ; n=11$ \\
\hline Fmr1 KO & LSO & Pearson's $r=0.895 ; p=0.0002 ; n=11$ \\
\hline \multicolumn{3}{|l|}{ ALDH1L1 vs. Synaptophysin } \\
\hline \multicolumn{3}{|l|}{ P6 } \\
\hline Wild type & VCN & Pearson's $r=-0.434 ; p=0.331 ; n=7$ \\
\hline Wild type & MNTB & Pearson's $r=0.155 ; p=0.740 ; n=7$ \\
\hline Wild type & LSO & Pearson's $r=0.550 ; p=0.201 ; n=7$ \\
\hline Fmr1 KO & VCN & Pearson's $r=0.376 ; p=0.359 ; n=8$ \\
\hline Fmr1 KO & MNTB & Pearson's $r=0.370 ; p=0.367 ; n=8$ \\
\hline$F m r 1 \mathrm{KO}$ & LSO & Pearson's $r=-0.398 ; p=0.329 ; n=8$ \\
\hline \multicolumn{3}{|r|}{ 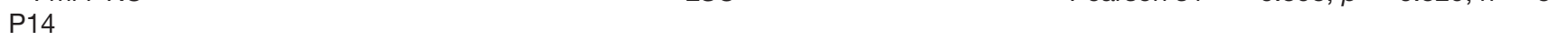 } \\
\hline Wild type & VCN & Pearson's $r=-0.126 ; p=0.747 ; n=9$ \\
\hline Wild type & MNTB & Pearson's $r=0.807 ; p=0.005 ; n=10$ \\
\hline Wild type & LSO & Pearson's $r=0.136 ; p=0.707 ; n=10$ \\
\hline Fmr1 KO & VCN & Pearson's $r=-0.077 ; p=0.857 ; n=8$ \\
\hline Fmr1 KO & MNTB & Pearson's $r=-0.301 ; p=0.431 ; n=9$ \\
\hline Fmr1 KO & LSO & Pearson's $r=-0.036 ; p=0.926 ; n=9$ \\
\hline
\end{tabular}

$\mathrm{P} 14$, the $\mathrm{I}_{\mathrm{SP}}$ ratios for both genotypes were somewhat higher than those previously published in adult mice (Rotschafer et al., 2015), suggesting that this phenotype continues to develop with synaptic maturation after hearing onset. The source of these increased VGAT terminals is likely from VNTB, the principal source of inhibitory input to MNTB (Albrecht et al., 2014). However, a previous study did not find any difference in GAD67 levels in the VNTB or in other auditory brainstem nuclei (McCullagh et al., 2017) in adult Fmr1 KO animals. This finding suggests that the mutation might lead to enhanced branching of the normal population of VNTB GAD67-positive cells to result in more exuberant terminals in MNTB in Fmr1 KO mice. In that study, a decrease in expression of the glycine transporter Glyt2 was seen, but only in the medial, high-frequency region of the MNTB. It is not known whether the shift from GABA to glycine is altered in Fmr1 $\mathrm{KO}$ mice. However, our results suggest that altered inhibitory input to MNTB is seen before hearing onset, before inhibition has matured in the auditory brainstem.

Our data suggest that increased VGAT expression drives the decrease in $\mathrm{I}_{\mathrm{SP}}$ in Fmr1 $\mathrm{KO}$ mice. There is other evidence, however, that calyx of Held volume may also grow larger in Fmr1 KO mice (Wang et al., 2015). Our interpretation is based on VGLUT2 expression only, and other excitatory presynaptic proteins may be affected in Fmr1 KO mice. Interestingly, despite an enlarged presynaptic terminal, cells in the Fmr1 KO MNTB did not show significant differences in firing behavior (Wang et al., 2015), presenting the possibility that a larger calyx of Held 
Table 5. Statistics for two-way ANOVA to identify effects of sex and genotype

\begin{tabular}{|c|c|c|c|}
\hline $\mathrm{P} 14$ & VCN & MNTB & LSO \\
\hline Nucleus size & $\begin{array}{l}\text { Sex: } F_{1,27}=0.546, p=0.466 ; \text { genotype: } \\
\qquad F_{1,27}=0.248, p=0.623 ; \text { interaction: } \\
F_{1,27}=0.289, p=0.595\end{array}$ & $\begin{array}{l}\text { Sex: } F_{1,27}=0.108, p=0.745 ; \text { genotype: } \\
\qquad F_{1,27}=5.877, p=0.022 ; \text { interaction: } \\
F_{1,27}=0.024, p=0.878\end{array}$ & $\begin{array}{l}\text { Sex: } F_{1,27}=0.669, p=0.421 ; \text { genotype: } \\
\qquad F_{1,27}=0.022, p=0.884 ; \text { interaction: } \\
F_{1,27}=3.438, p=0.075\end{array}$ \\
\hline Number of cells & $\begin{array}{l}\text { Sex: } F_{1,27}=0.459, p=0.504 ; \text { genotype: } \\
\qquad F_{1,27}=0.174, p=0.680 ; \text { interaction: } \\
F_{1,27}=0.998, p=0.327\end{array}$ & $\begin{array}{l}\text { Sex: } F_{1,27}=0.032, p=0.860 ; \text { genotype: } \\
\qquad F_{1,27}=0.298, p=0.590 ; \text { interaction: } \\
F_{1,27}=0.740, p=0.397\end{array}$ & $\begin{array}{l}\text { Sex: } F_{1,27}=0.004, p=0.947 ; \text { genotype: } \\
\qquad F_{1,27}=1.698, p=0.204 ; \text { interaction: } \\
F_{1,27}=3.140, p=0.088\end{array}$ \\
\hline Cell size & $\begin{array}{l}\text { Sex: } F_{1,26}=1.106, p=0.303 ; \text { genotype: } \\
\qquad F_{1,26}=2.796, p=0.107 ; \text { interaction: } \\
F_{1,26}=0.086, p=0.771\end{array}$ & $\begin{array}{l}\text { Sex: } F_{1,16}=0.225, p=0.642 ; \text { genotype: } \\
F_{1,16}=21.198, p<0.001 ; \text { interaction: } \\
F_{1,16}=3.111, p=0.097\end{array}$ & $\begin{array}{l}\text { Sex: } F_{1,26}=0.009, p=0.925 \text {; genotype: } \\
\qquad F_{1,26}=14.746, p<0.001 ; \text { interaction: } \\
F_{1,26}=0.392, p=0.537\end{array}$ \\
\hline VGLUT & $\begin{array}{l}\text { Sex: } F_{1,22}=4.253, p=0.051 ; \text { genotype: } \\
\qquad F_{1,22}=0.049, p=0.828 ; \text { interaction: } \\
F_{1,22}=0.108, p=0.746\end{array}$ & $\begin{array}{l}\text { Sex: } F_{1,6}=1.265, p=0.304 ; \text { genotype: } \\
\qquad F_{1,6}=3.258, p=0.121 ; \text { interaction: } \\
F_{1,6}=5.738, p=0.054\end{array}$ & $\begin{array}{l}\text { Sex: } F_{1,22}=0.789, p=0.384 ; \text { genotype: } \\
\qquad F_{1,22}=0.009, p=0.927 ; \text { interaction: } \\
F_{1,22}=0.268, p=0.610\end{array}$ \\
\hline VGAT & $\begin{array}{l}\text { Sex: } F_{1,22}=2.066, p=0.165 ; \text { genotype: } \\
\qquad F_{1,22}=0.488, p=0.492 ; \text { interaction: } \\
F_{1,22}=0.591, p=0.450\end{array}$ & $\begin{aligned} \text { Sex: } F_{1,6}=0.196, p=0.674 ; \text { genotype: } \\
F_{1,6}=16.028, p=0.007 ; \text { interaction: } \\
F_{1,6}=1.159, p=0.323\end{aligned}$ & $\begin{array}{l}\text { Sex: } F_{1,22}=1.510, p=0.232 ; \text { genotype: } \\
\qquad F_{1,22}=0.551, p=0.466 ; \text { interaction: } \\
F_{1,22}=0.962, p=0.337\end{array}$ \\
\hline $\mathrm{I}_{\mathrm{SP}}$ & $\begin{array}{l}\text { Sex: } F_{1,22}=1.187, p=0.288 ; \text { genotype: } \\
\qquad F_{1,22}=0.404, p=0.531 ; \text { interaction: } \\
F_{1,22}=2.715, p=0.114\end{array}$ & $\begin{array}{l}\text { Sex: } F_{1,6}=0.099, p=0.764 ; \text { genotype: } \\
\quad F_{1,6}=6.793, p=0.040 ; \text { interaction: } \\
F_{1,6}=4.950, p=0.068\end{array}$ & $\begin{array}{l}\text { Sex: } F_{1,22}=0.646, p=0.430 ; \text { genotype: } \\
\qquad F_{1,22}=4.515, p=0.055 ; \text { interaction: } \\
F_{1,22}=0.668, p=0.422\end{array}$ \\
\hline Synaptophysin & $\begin{array}{l}\text { Sex: } F_{1,16}=1.165, p=0.296 ; \text { genotype: } \\
\quad F_{1,16}=1.537, p=0.233 ; \text { interaction: } \\
F_{1,16}=1.072, p=0.316\end{array}$ & $\begin{array}{l}\text { Sex: } F_{1,6}=0.224, p=0.653 ; \text { genotype: } \\
\quad F_{1,6}=2.765, p=0.147 ; \text { interaction: } \\
F_{1,6}=0.910, p=0.377\end{array}$ & $\begin{array}{l}\text { Sex: } F_{1,16}=0.824, p=0.377 \text {; genotype: } \\
\qquad F_{1,16}=31.222, p<0.001 ; \text { interaction: } \\
F_{1,16}=1.103, p=0.309\end{array}$ \\
\hline IBA1 & $\begin{array}{l}\text { Sex: } F_{1,27}=1.589, p=0.218 ; \text { genotype: } \\
\qquad F_{1,27}=1.192, p=0.285 ; \text { interaction: } \\
F_{1,27}=2.381, p=0.134\end{array}$ & $\begin{array}{l}\text { Sex: } F_{1,27}=0.268, p=0.609 ; \text { genotype: } \\
\qquad F_{1,27}=0.569, p=0.457 ; \text { interaction: } \\
F_{1,27}=0.125, p=0.727\end{array}$ & $\begin{array}{l}\text { Sex: } F_{1,27}=0.094, p=0.761 ; \text { genotype: } \\
\qquad F_{1,27}=0.075, p=0.786 ; \text { interaction: } \\
F_{1,27}=1.556, p=0.223\end{array}$ \\
\hline ALDH1L1 & $\begin{array}{l}\text { Sex: } F_{1,18}=0.109, p=0.745 ; \text { genotype: } \\
\qquad F_{1,18}=4.855, p=0.041 ; \text { interaction: } \\
F_{1,18}=3.020, p=0.099\end{array}$ & $\begin{array}{l}\text { Sex: } F_{1,20}=0.215, p=0.648 ; \text { genotype: } \\
\qquad F_{1,20}=1.025, p=0.323 ; \text { interaction: } \\
F_{1,20}=0.149, p=0.703\end{array}$ & $\begin{array}{l}\text { Sex: } F_{1,20}=0.495, p=0.490 ; \text { genotype: } \\
\quad F_{1,20}=4.130, p=0.056 ; \text { interaction: } \\
F_{1,20}=2.392, p=0.138\end{array}$ \\
\hline
\end{tabular}

may be countered by an increase in presynaptic inhibitory input in Fmr1 KO. While MNTB cells may have larger calyces of Held, work done in Fmr1 KO rats found fewer MNTB neurons received input from VCN globular bushy cells (Ruby et al., 2015).

Previous studies demonstrated an increase in VGLUT expression in the adult LSO (Rotschafer et al., 2015; Garcia-Pino et al., 2017), as well as an increase in VGAT (Rotschafer et al., 2015). Although neither VGLUT nor VGAT differences were noted in LSO during postnatal development, we found a significant increase in synaptophysin, a broad marker for presynaptic terminals, in LSO in Fmr1 KO mice at both $\mathrm{P} 6$ and P14. This observation suggests that overall input is increased. The $I_{S P}$ ratio was significantly lower in mutants than in wild-type mice at P14; this difference is not evident in adults (Rotschafer et al., 2015). Interestingly, no differences were seen between wild-type mice and Fmr1 KO mice in adult LSO using GlyT2 as a marker of inhibitory input (Garcia-Pino et al., 2017). While VGAT is expressed in both GABAergic and glycinergic inputs (Dumoulin et al., 1999), these findings highlight the possibility that loss of FMRP might differentially affect the expression of these presynaptic markers.

\section{Glial cells in Fmr1 KO auditory brainstem nuclei}

Microglia have several roles in synaptic maturation, neuronal homeostasis, and immune responses (Hanisch, 2002, 2013; Hanisch et al., 2004). Notably, phagocytotic and neuroprotective functions of microglia are impaired in various autism spectrum disorders (Arcuri et al., 2017; Lee et al., 2017). Astrocytes are known to shape synapses and dendritic arbors; wild-type hippocampal neurons cultured with Fmr1 KO astrocytes adopted a dendritic morphology similar to that found in Fmr1 KO mice (Jacobs et al., 2010, 2016).

Typically, mice steadily gain both microglia and astrocytes in the auditory brainstem between P0 and P14 (Dinh et al., 2014) Microglia and astrocytes can be found in close apposition to developing calyces in MNTB (Dinh et al., 2014). We found that microglia develop normally in the auditory brainstem of Fmr1 KO mice, but that astrocytes are elevated in VCN and LSO at P14. Microglia were positively correlated with VGLUT in the P6 MNTB in Fmr1 KO mice. Astrocytes were strongly positively correlated with both VGLUT and VGAT in P14 in LSO in Fmr1 KO mice, but not in wild-type mice. The findings suggest that glial cells represent an important factor in establishing excitatory and inhibitory synapses and that their role in synaptic development may be enhanced in FXS.

\section{Lack of sex differences}

FXS is far more common and severe in males, as they lack an additional X-chromosome that may partially compensate for Fmr1 inactivation (Inaba et al., 2013; Godler et al., 2015). The female Fmr1 KO mice used here contain two alleles of the Fmr1 KO, one on each X-chromosome. Male and female Fmr1 KO mice show differences in behavioral measures (Nolan et al., 2017), vocalization production (Reynolds et al., 2016), and neurophysiology (Giráldez-Pérez et al., 2013; Lokanga et al., 2014; Scremin et al., 2015), but other studies showed similar behaviors between the sexes (Ding et al., 2014). We found that the auditory brainstem phenotypes we observed did not differ between males and females, suggesting predominantly common molecular mechanisms that are not selectively altered by the mutation. 


\section{Conclusion}

In addition to enhanced responses to sensory stimuli, individuals with FXS have a host of symptoms that are confined to childhood (reviewed in (Turk, 2011). This invites the question of whether the symptoms of FXS result from disrupted brain development during critical periods, or from a general and ongoing effect of loss of FMRP. Here, we found delays in auditory brainstem nucleus development and imbalances in synaptic input, which potentially contribute to the hyperacusis found in adult Fmr1 $\mathrm{KO}$ mice. Our findings show developmental effects at very young ages, implying that early developmental events initiate some of the auditory phenotypes in FXS.

\section{References}

Albrecht O, Dondzillo A, Mayer F, Thompson JA, Klug A (2014) Inhibitory projections from the ventral nucleus of the trapezoid body to the medial nucleus of the trapezoid body in the mouse. Front Neural Circuits 8:83. CrossRef Medline

Arcuri C, Mecca C, Bianchi R, Giambanco I, Donato R (2017) The pathophysiological role of microglia in dynamic surveillance, phagocytosis and structural remodeling of the developing CNS. Front Mol Neurosci 10:191. CrossRef Medline

Bailey DB, Hatton DD, Skinner M (1998) Early developmental trajectories of males with fragile X syndrome. Am J Ment Retard 103: 29-39. CrossRef Medline

Baranek GT, Danko CD, Skinner ML, Bailey DB, Jr., Hatton DD, Roberts JE, Mirrett PL (2005) Video analysis of sensory-motor features in infants with fragile $X$ syndrome at 9-12 months of age. J Autism Dev Disord 35:645-656. CrossRef

Bassell GJ, Warren ST (2008) Fragile X syndrome: loss of local mRNA regulation alters synaptic development and function. Neuron 60: 201-214. CrossRef Medline

Beebe K, Wang Y, Kulesza R (2014) Distribution of fragile X mental retardation protein in the human auditory brainstem. Neuroscience 273:79-91. CrossRef Medline

Belser RC, Sudhalter V (2001) Conversational characteristics of children with fragile X syndrome: repetitive speech. Am J Ment Retard 106:28-38. CrossRef Medline

Billups B (2005) Colocalization of vesicular glutamate transporters in the rat superior olivary complex. Neurosci Lett 382:66-70. CrossRef Medline

Castrén M, Pääkkönen A, Tarkka IM, Ryynänen M, Partanen J (2003) Augmentation of auditory $\mathrm{N} 1$ in children with fragile $\mathrm{X}$ syndrome. Brain Topography 15:165-171. Medline

Chen L, Toth M (2001) Fragile X mice develop sensory hyperreactivity to auditory stimuli. Neuroscience 103:1043-1050. Medline

Contractor A, Klyachko VA, Portera-Cailliau C (2015) Altered neuronal and circuit excitability in fragile $X$ syndrome. Neuron 87:699715. CrossRef Medline

Ding Q, Sethna F, Wang H (2014) Behavioral analysis of male and female Fmr1 knockout mice on C57BL/6 background. Behav Brain Res 271:72-78. CrossRef Medline

Dinh ML, Koppel SJ, Korn MJ, Cramer KS (2014) Distribution of glial cells in the auditory brainstem: normal development and effects of unilateral lesion. Neuroscience 278:237-252. CrossRef Medline

Dumoulin A, Rostaing P, Bedet C, Lévi S, Isambert MF, Henry JP, Triller A, Gasnier B (1999) Presence of the vesicular inhibitory amino acid transporter in GABAergic and glycinergic synaptic terminal boutons. J Cell Sci 112: (Pt 6):811-823.

Feinstein C, Reiss AL (1998) Autism: the point of view from fragile $X$ studies. J Autism Dev Disord 28:393-405. Medline

Fidler DJ, Philofsky A, Hepburn SL (2007) Language phenotypes and intervention planning: bridging research and practice. Ment Retard Dev Disabil Res Rev 13:47-57. CrossRef
Finestack LH, Richmond EK, Abbeduto L (2009) Language development in individuals with fragile $X$ syndrome. Top Lang Disord 29:133-148. Medline

Frankland PW, Wang Y, Rosner B, Shimizu T, Balleine BW, Dykens EM, Ornitz EM, Silva AJ (2004) Sensorimotor gating abnormalities in young males with fragile $\mathrm{X}$ syndrome and Fmr1-knockout mice. Mol Psychiatry 9:417-425. CrossRef Medline

Garcia-Pino E, Gessele N, Koch U (2017) Enhanced excitatory connectivity and disturbed sound processing in the auditory brainstem of fragile X mice. J Neurosci 2310-2316.

Gholizadeh S, Halder SK, Hampson DR (2015) Expression of fragile $X$ mental retardation protein in neurons and glia of the developing and adult mouse brain. Brain Res 1596:22-30. CrossRef Medline

Gibson JR, Bartley AF, Hays SA, Huber KM (2008) Imbalance of neocortical excitation and inhibition and altered UP states reflect network hyperexcitability in the mouse model of fragile $X$ syndrome. J Neurophysiol 100:2615-2626. CrossRef Medline

Giráldez-Pérez RM, Avila MN, Feijóo-Cuaresma M, Heredia R, De Diego-Otero Y, Real M, Guirado S (2013) Males but not females show differences in calbindin immunoreactivity in the dorsal thalamus of the mouse model of fragile $X$ syndrome. J Comp Neur 521:894-911. CrossRef

Godler DE, Inaba Y, Schwartz CE, Bui QM, Shi EZ, Li X, Herlihy AS, Skinner C, Hagerman RJ, Francis D, Amor DJ, Metcalfe SA, Hopper JL, Slater HR (2015) Detection of skewed X-chromosome inactivation in fragile $X$ syndrome and $X$ chromosome aneuploidy using quantitative melt analysis. Expert Rev Mol Med 17:e13. CrossRef

Gothelf D, Furfaro JA, Hoeft F, Eckert MA, Hall SS, O'Hara R, Erba HW, Ringel J, Hayashi KM, Patnaik S, Golianu B, Kraemer HC, Thompson PM, Piven J, Reiss AL (2008) Neuroanatomy of fragile $X$ syndrome is associated with aberrant behavior and the fragile $X$ mental retardation protein (FMRP). Ann Neurol 63:40-51. CrossRef Medline

Hagerman RJ, Jackson AW, Levitas A, Rimland B, Braden M (1986) An analysis of autism in fifty males with the fragile $X$ syndrome. Am J Med Genet 23:359-374. Medline

Hanisch UK (2002) Microglia as a source and target of cytokines. Glia 40:140-155. CrossRef Medline

Hanisch UK (2013) Functional diversity of microglia-how heterogeneous are they to begin with? Front Cell Neurosci 7:65. CrossRef Medline

Hanisch UK, van Rossum D, Xie Y, Gast K, Misselwitz R, Auriola S, Goldsteins G, Koistinaho J, Kettenmann H, Möller T (2004) The microglia-activating potential of thrombin: the protease is not involved in the induction of proinflammatory cytokines and chemokines. J Biol Chem 279:51880-51887. CrossRef

Hays SA, Huber KM, Gibson JR (2011) Altered neocortical rhythmic activity states in Fmr1 KO mice are due to enhanced mGluR5 signaling and involve changes in excitatory circuitry. J Neurosci 31:14223-14234. CrossRef Medline

Hessl D, Berry-Kravis E, Cordeiro L, Yuhas J, Ornitz EM, Campbell A, Chruscinski E, Hervey C, Long JM, Hagerman RJ (2009) Prepulse inhibition in fragile $X$ syndrome: feasibility, reliability, and implications for treatment. Am J Med Genet B Neuropsychiatr Genet 150B:545-553. CrossRef Medline

Hoffpauir BK, Grimes JL, Mathers PH, Spirou GA (2006) Synaptogenesis of the calyx of Held: rapid onset of function and one-toone morphological innervation. J Neurosci 26:5511-5523. CrossRef Medline

Hoffpauir BK, Kolson DR, Mathers PH, Spirou GA (2010) Maturation of synaptic partners: functional phenotype and synaptic organization tuned in synchrony. J Physiol 588:4365-4385. CrossRef Medline

Holcomb PS, Hoffpauir BK, Hoyson MC, Jackson DR, Deerinck TJ, Marrs GS, Dehoff M, Wu J, Ellisman MH, Spirou GA (2013) Synaptic inputs compete during rapid formation of the calyx of Held: a new model system for neural development. J Neurosci 33: 12954-12969. CrossRef Medline 
Inaba Y, Herlihy AS, Schwartz CE, Skinner C, Bui QM, Cobb J, Shi EZ, Francis D, Arvaj A, Amor DJ, Pope K, Wotton T, Cohen J, Hewitt JK, Hagerman RJ, Metcalfe SA, Hopper JL, Loesch DZ, Slater HR, Godler DE (2013) Fragile X-related element 2 methylation analysis may provide a suitable option for inclusion of fragile $X$ syndrome and/or sex chromosome aneuploidy into newborn screening: a technical validation study. Genet Med 15:290-298. CrossRef Medline

Incorpora G, Sorge G, Sorge A, Pavone L (2002) Epilepsy in fragile X syndrome. Brain Dev 24:766-769. Medline

Jacobs S, Nathwani M, Doering LC (2010) Fragile X astrocytes induce developmental delays in dendrite maturation and synaptic protein expression. BMC Neurosci 11:132. CrossRef Medline

Jacobs S, Cheng C, Doering LC (2016) Hippocampal neuronal subtypes develop abnormal dendritic arbors in the presence of fragile $X$ astrocytes. Neuroscience 324:202-217. CrossRef Medline

Knoth IS, Lippé S (2012) Event-related potential alterations in fragile $X$ syndrome. Front Hum Neurosci 6:264. CrossRef Medline

Knoth IS, Vannasing P, Major P, Michaud JL, Lippé S (2014) Alterations of visual and auditory evoked potentials in fragile $X$ syndrome. Int J Dev Neurosci 36:90-97. CrossRef Medline

Kulesza RJ, Mangunay K (2008) Morphological features of the medial superior olive in autism. Brain Res 1200:132-137. CrossRef Medline

Kulesza RJ, Lukose R, Stevens LV (2011) Malformation of the human superior olive in autistic spectrum disorders. Brain Res 1367:360371. CrossRef Medline

Kuwabara N, Zook JM (1992) Projections to the medial superior olive from the medial and lateral nuclei of the trapezoid body in rodents and bats. J Comp Neur 324:522-538. CrossRef Medline

Lee AS, Azmitia EC, Whitaker-Azmitia PM (2017) Developmental microglial priming in postmortem autism spectrum disorder temporal cortex. Brain Behav Immun 62:193-202. CrossRef Medline

Lokanga RA, Zhao XN, Usdin K (2014) The mismatch repair protein $\mathrm{MSH} 2$ is rate limiting for repeat expansion in a fragile $\mathrm{X}$ premutation mouse model. Hum Mutat 35:129-136. CrossRef

Lovelace JW, Wen TH, Reinhard S, Hsu MS, Sidhu H, Ethell IM, Binder DK, Razak KA (2016) Matrix metalloproteinase-9 deletion rescues auditory evoked potential habituation deficit in a mouse model of fragile X syndrome. Neurobiol Dis 89:126-135. CrossRef

Lukose R, Schmidt E, Wolski TP, Murawski NJ, Kulesza RJ (2011) Malformation of the superior olivary complex in an animal model of autism. Brain Res 1398:102-112. CrossRef

McCullagh EA, Salcedo E, Huntsman MM, Klug A (2017) Tonotopic alterations in inhibitory input to the medial nucleus of the trapezoid body in a mouse model of fragile $X$ syndrome. J Comp Neur 525:3543-3562. CrossRef

Miller LJ, McIntosh DN, McGrath J, Shyu V, Lampe M, Taylor AK, Tassone F, Neitzel K, Stackhouse T, Hagerman RJ (1999) Electrodermal responses to sensory stimuli in individuals with fragile $X$ syndrome: a preliminary report. Am J Med Genet 83:268-279. Medline

Moore MJ, Caspary DM (1983) Strychnine blocks binaural inhibition in lateral superior olivary neurons. J Neurosci 3:237-242. Medline

Morest DK (1968) The growth of synaptic endings in the mammalian brain: a study of the calyces of the trapezoid body. Z Anat Entwicklungsgesch 127:201-220. Medline

Musumeci SA, Ferri R, Elia M, Colognola RM, Bergonzi P, Tassinari CA (1991) Epilepsy and fragile $X$ syndrome: a follow-up study. Am J Med Genet 38:511-513. Medline

Musumeci SA, Hagerman RJ, Ferri R, Bosco P, Dalla Bernardina B, Tassinari CA, De Sarro GB, Elia M (1999) Epilepsy and EEG findings in males with fragile X syndrome. Epilepsia 40:1092-1099. Medline

Musumeci SA, Bosco P, Calabrese G, Bakker C, De Sarro GB, Elia M, Ferri R, Oostra BA (2000) Audiogenic seizures susceptibility in transgenic mice with fragile $X$ syndrome. Epilepsia 41:19-23. CrossRef

Musumeci SA, Calabrese G, Bonaccorso CM, D'Antoni S, Brouwer JR, Bakker CE, Elia M, Ferri R, Nelson DL, Oostra BA, Catania MV
(2007) Audiogenic seizure susceptibility is reduced in fragile $X$ knockout mice after introduction of FMR1 transgenes. Exp Neurol 203:233-240. CrossRef Medline

Nielsen DM, Derber WJ, McClellan DA, Crnic LS (2002) Alterations in the auditory startle response in Fmr1 targeted mutant mouse models of fragile $X$ syndrome. Brain Res 927:8-17. Medline

Nolan SO, Reynolds CD, Smith GD, Holley AJ, Escobar B, Chandler MA, Volquardsen M, Jefferson T, Pandian A, Smith T, Huebschman J, Lugo JN (2017) Deletion of Fmr1 results in sex-specific changes in behavior. Brain Behav 7:e00800. CrossRef Medline

O'Donnell WT, Warren ST (2002) A decade of molecular studies of fragile X syndrome. Annu Rev Neurosci 25:315-338.

Pasic TR, Rubel EW (1991) Cochlear nucleus cell size is regulated by auditory nerve electrical activity. Otolaryngol Head Neck Surg 104:6-13. CrossRef Medline

Reynolds CD, Nolan SO, Jefferson T, Lugo JN (2016) Sex-specific and genotype-specific differences in vocalization development in FMR1 knockout mice. Neuroreport 27:1331-1335. CrossRef Medline

Roberts J, Hennon EA, Anderson K, Roush J, Gravel J, Skinner M, Misenheimer J, Reitz P (2005) Auditory brainstem responses in young males with fragile $X$ syndrome. J Speech Lang Hearing Res 48:494-500. CrossRef

Rojas DC, Benkers TL, Rogers SJ, Teale PD, Reite ML, Hagerman RJ (2001) Auditory evoked magnetic fields in adults with fragile $X$ syndrome. Neuroreport 12:2573-2576. Medline

Rotschafer S, Razak K (2013) Altered auditory processing in a mouse model of fragile $X$ syndrome. Brain Res 1506:12-24. CrossRef Medline

Rotschafer SE, Marshak S, Cramer KS (2015) Deletion of Fmr1 alters function and synaptic inputs in the auditory brainstem. PLoS ONE 10:e0117266CrossRef Medline

Ruby K, Falvey K, Kulesza RJ (2015) Abnormal neuronal morphology and neurochemistry in the auditory brainstem of Fmr1 knockout rats. Neuroscience 303:285-298. CrossRef Medline

Schneider A, Leigh MJ, Adams P, Nanakul R, Chechi T, Olichney J, Hagerman R, HessI D (2013) Electrocortical changes associated with minocycline treatment in fragile $X$ syndrome. J Psychopharmacol 27:956-963. CrossRef Medline

Scremin OU, Roch M, Norman KM, Djazayeri S, Liu YY (2015) Brain acetylcholine and choline concentrations and dynamics in a murine model of the fragile $X$ syndrome: age, sex and region-specific changes. Neuroscience 301:520-528. CrossRef

Sierksma MC, Tedja MS, Borst JG (2017) In vivo matching of postsynaptic excitability with spontaneous synaptic inputs during formation of the rat calyx of Held synapse. J Physiol 595:207-231. CrossRef Medline

St Clair DM, Blackwood DH, Oliver CJ, Dickens P (1987) P3 abnormality in fragile $X$ syndrome. Biol Psychiatry 22:303-312. Medline

Strumbos JG, Polley DB, Kaczmarek LK (2010) Specific and rapid effects of acoustic stimulation on the tonotopic distribution of Kv3.1b potassium channels in the adult rat. Neuroscience 167: 567-572. CrossRef Medline

Tollin DJ (2003) The lateral superior olive: a functional role in sound source localization. Neuroscientist 9:127-143. CrossRef Medline

Turk J (2011) Fragile X syndrome: lifespan developmental implications for those without as well as with intellectual disability. Curr Opin Psychiatry 24:387-397. CrossRef Medline

Van der Molen MJ, Van der Molen MW, Ridderinkhof KR, Hamel BC, Curfs LM, Ramakers GJ (2012a) Auditory and visual cortical activity during selective attention in fragile $X$ syndrome: a cascade of processing deficiencies. Clin Neurophysiol 123:720-729.

Van der Molen MJ, Van der Molen MW, Ridderinkhof KR, Hamel BC, Curfs LM, Ramakers GJ (2012b) Auditory change detection in fragile $X$ syndrome males: a brain potential study. Clin Neurophysiol 123:1309-1318

Wang HC, Bergles DE (2015) Spontaneous activity in the developing auditory system. Cell Tissue Res 361:65-75. CrossRef Medline

Wang T, de Kok L, Willemsen R, Elgersma Y, Borst JG (2015) In vivo synaptic transmission and morphology in mouse models of tuber- 
ous sclerosis, fragile $X$ syndrome, neurofibromatosis type 1 , and Costello syndrome. Front Cell Neurosci 9:234. CrossRef Medline Wang Y, Sakano H, Beebe K, Brown MR, de Laat R, Bothwell M, Kulesza RJ, Rubel EW (2014) Intense and specialized dendritic localization of the fragile $\mathrm{X}$ mental retardation protein in binaural brainstem neurons: a comparative study in the alligator, chicken, gerbil, and human. J Comp Neur 522:2107-2128. CrossRef

Weatherstone $\mathrm{JH}$, Kopp-Scheinpflug C, Pilati N, Wang Y, Forsythe ID, Rubel EW, Tempel BL (2017) Maintenance of neuronal size gradient in MNTB requires sound-evoked activity. J Neurophysiol 117:756-766. CrossRef Medline

Yuhas J, Cordeiro L, Tassone F, Ballinger E, Schneider A, Long JM, Ornitz EM, HessI D (2011) Sensorimotor gating in idiopathic autism and autism associated with fragile $\mathrm{X}$ syndrome. J Autism Dev Disord 41:248-253. CrossRef Medline

Zorio DA, Jackson CM, Liu Y, Rubel EW, Wang Y (2017) Cellular distribution of the fragile $X$ mental retardation protein in the mouse brain. J Comp Neur 525:818-849. CrossRef 